\title{
Medical treatment of gastroesophageal reflux disease: Options and priorities
}

\author{
ABR THOMSON, MD, PHD, FRCPC, FACP, FACG, FRS
}

ABR THOMSON. Medical treatment of gastroesophageal reflux disease: Options and priorities. Can J Gastroenterol 1993;7(4):364-379. Gastroesophageal reflux disease (GERD) represents a spectrum of symptoms and of reflux damage to the esophagus. This reflux damage is due to prolonged acid exposure of the esophagus arising from an imbalance between protective motility factors and aggressive acid secretory factors. Initially, patients may be managed by modifying food intake and by supportive antigravity measures. However, many individuals will require drug therapy. Symptomatic relief can be achieved with prokinetic agents, antacids, sucralfate suspension, $\mathrm{H}_{2}$-receptor antagonists and $\mathrm{H}^{+}, \mathrm{K}^{+}$-ATPase pump blockers. There are limitations in the study design of experiments which have compared one agent with another. Accepting these design restrictions, it would appear that pump blockers lead to higher rates of endoscopic healing than the use of standard doses of $\mathrm{H}_{2}$-receptor antagonists. However, higher doses of $\mathrm{H}_{2}$-receptor antagonists will likely give higher rates of symptomatic relief and endoscopic healing of GERD. Recurrence of symptoms and esophagitis occur in a high proportion of patients with GERD, and some patients may need to be considered for maintenance therapy.

Key Words: Gastroesophageal reflux disease (GERD), Recurrence, Symptoms

\section{Traitement médical du reflux gastro-oesophagien: Options et priorités}

RÉSUMÉ: Le reflux gastro-oesophagien se manifeste par un vaste éventail de symptômes et de lésions au niveau de l'oesophage. Les lésions attribuables au contentu gastrique régurgité résultent d'une exposition prolongée de l'oesophage

Division of Gastroenterology, Nutrition and Metabolism Research Group, Department of Medicine, University of Alberta, Edmonton, Alberta

Correspondence and reprints: Dr ABR Thomson, 519 Robert Newton Research Building, University of Alberta, Edmonton, Alberta T6G 2C2. Telephone (403) 492-6490/6284, Fax (403) $492-7964$

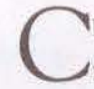
URRENT ADVERTISEMENTS IN THE medical literature for products to treat gastroesophageal reflux disease (GERD) highlight the severity of symptoms and the dynamic aspect of the 'fire in the esophagus' which leads to heartburn (pyrosis). Of course, the most common cause of esophagitis is the presence of gastric acid in this tubular organ, but esophagitis has also been described in association with the presence of gastroesophageal reflux of bile and trypsin, radiation therapy, lye ingestion, lodging of pills in the esophagus or infections such as Candida albicans and herpes (Table 1).

Acid-induced esophagitis results from the reflux of gastric acid into the esophagus. Whether esophagitis develops depends upon the duration of acid exposure and the concentration of the acidic refluxed material; this exposure results from abnormal lower esophageal sphincter relaxation, impaired clearance of refluxed acid and a vaguely defined, but useful term, esophageal 'mucosal defence'. The acid exposure of the esophagus also is influenced by the intragastric $\mathrm{pH}$ (and therefore intraesophageal $\mathrm{pH}$ ) as well as by the volume of acid in the stomach 
à l'acide et à un déséquilibre entre les facteurs de motilité protecteurs et les facteurs nocifs des sécrétions acides. Initialement, les patients peuvent être traités par une modification de leur alimentation et par des mesures d'appoint antigravité. Cependant, plusieurs individus requerront un traitement médicamenteux. Le soulagement des symptômes peut être obtenu par des agents prokinétiques, des antiacides, des suspensions de sucralfate, des anti- $\mathrm{H}_{2}$ et des inhibiteurs de la pompe à protons. Il y a des limites au niveau de la conception de l'étude portant sur des essais qui comparaient les agents entre eux. Si l'on accepte ces restrictions au niveau du modele, il semble que les inhibiteurs de la pompe à protons amènent des taux de cicatrisation plus élevés, endoscopie à l'appui, que les doses standard d'anti- $\mathrm{H}_{2}$. Cependant, des doses plus fortes d'anti-H $\mathrm{H}_{2}$ sont susceptibles de générer des taux plus élevés de soulagement des symptômes et de cicatrisation, endoscopie à l'appui. La récidive des symptômes et de l'oesophagite elle-même se produit chez une forte proportion de patients atteints de reflux gastro-oesophagien et certains d'entre eux seront des candidats au traitement d'entretien.

which, in turn, is influenced by the gastric emptying rate, and by the gastric basal and stimulated acid outputs.

Ambulatory esophageal $\mathrm{pH}$ monitoring has proven to be useful to study the pathogenesis and management of patients with GERD and has demonstrated, for example, the importance of daytime as well as nighttime reflux (1 6) and the aggravating effect of smoking on gastroesophageal reflux (7). The most commonly used parameters are the reflux index (percentage of the investigation time with a $\mathrm{pH}$ less than 4), number of episodes with a $\mathrm{pH}$ less than 4 , number of episodes with a $\mathrm{pH}$ less than 4 lasting longer than 5 mins, duration of the longest episode with a $\mathrm{pH}$ less than 4 and the area in which the $\mathrm{pH}$ is less than 4 (8). Both esophageal $\mathrm{pH}$ and manometry can be combined $(9,10)$, and measurements of intragastric and intraesophageal $\mathrm{pH}$ may be made concurrently (11), to be used to predict the therapeutic efficacy of a treatment intervention.

\section{PATHOGENESIS}

For at least a decade it has been useful conceptually to approach the pathogenesis of peptic ulcer disease as an imbalance between aggressive and defensive factors. This is also a useful concept in considering the pathogenesis of GERD (Table 2). The reduced basal lower esophageal sphincter pressure and the increased transient lower esophageal sphincter relaxation presumably are due to defective neural control of the smooth muscle relaxation. Clinically these motility abnormalities may readily be documented, but the molecular basis for the defective neuromuscular coordination is unknown. On the aggressive side, the pathogenesis of GERD appears to be related to the simple concept of too much acid in the wrong place. Thus, the number and duration of reflux episodes increase due to excessive lower esophageal sphincter relaxation, acid exposure time in the esophagus rises because of impaired clearance of acid and epithelial damage occurs because of defective mucosal defence. There may also be abnormalities in gastric acid secretion in some patients with GERD.

Mild, infrequent gastroesophageal reflux is a normal phenomenon - it occurs in individuals who do not complain of heartburn and who do not have esophagitis. Different criteria have been established for differentiating normal from abnormal gastroesophageal reflux, and threshold intraesophageal $\mathrm{pHs}$ of 4 or 5 have been designated as being associated with GERD. Abnormal

reflux is denoted to occur if a reflux episode is associated with a $\mathrm{pH}$ less than 4 or a drop of interesophageal $\mathrm{pH}$ by 1 . Similarly, interesophageal $\mathrm{pH}$ can be monitored over a $24 \mathrm{~h}$ interval. When more than $7 \%$ of interesophageal $\mathrm{pH}$ values are less than 4 , the gastroesophageal reflux is denoted $a b$ normal.

What is the relative contribution of the aggressive and defensive factors? Reduced lower esophageal sphincter pressure is common in patients with GERD; for example, when KlinkenbergKnol and Meeuwissen (11) performed combined esophageal and intragastric $\mathrm{pH}$ monitoring, and esophageal manometry in 19 patients with 'resistant' GERD, 18 of 19 had reduced lower esophageal sphincter pressure and 12 of 19 had reduced clearance of refluxed acid.

TABLE 3

Prevalence of gastric hypersecretion and defective lower esophageal sphincter in GERD

\begin{tabular}{lccc}
\hline & Normal secretion & Hypersecretion & Total \\
\hline Normal sphincter & 11 & 10 & $21(28 \%)$ \\
Defective sphincter & 43 & 11 & $54(72 \%)$ \\
Total & 54 of $75(72 \%)$ & 21 of $75(28 \%)$ & 75 of $75(100 \%)$ \\
\hline
\end{tabular}

Reproduced with permission from Barlow et al. Arch Surg 1989:124:937-40 


\section{TABLE 4 \\ Lifestyle considerations: Nondrug therapy in GERD}

- $\quad$ Eating small, nonfatty meals

- Avoiding smoking

- Avoiding excess use of caffeine, chocolate, alcohol and acidic or spicy foods

- Discerning the cause of direct pain

- Remaining upright after meals

- Avoiding straining or tight-fitting garments

- Maintaining ideal weight

- Elevating head of bed
TABLE 5 Medications which can lead to damage of the esophageal mucosa

- Progesterone

- Theophylline

- Prostaglandin $E_{1}$

- Prostaglandin $E_{2}$

- Prostaglandin $\mathrm{A}_{2}$

- Anticholinergics

- Beta-agonists

- Alpha-antagonists

- Dopamine

- Diazepam

- Opiates

- Calcium channel blockers

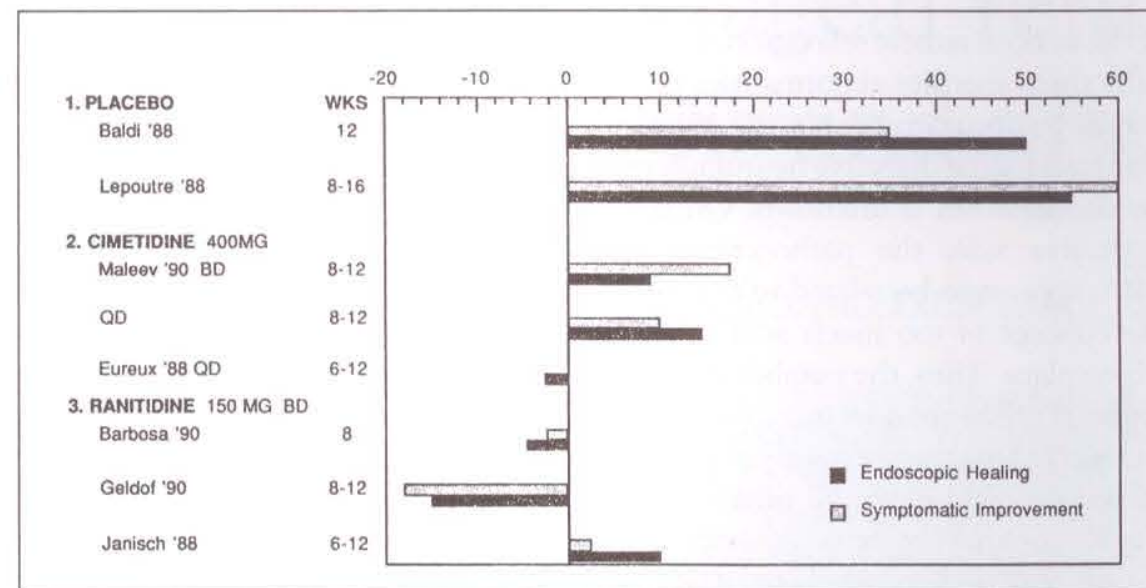

Figure 1) Therapeutic gain for treatment of moderately severe reflux esophagitis: cisapride $10 \mathrm{mg}$ qid versus placebo, cimetidine or ranitidine. (Adapted with permission from Tytgat et al. Scand J Gastroenterol 1990;25[Suppl175]:1-12)
While it is accepted that acid in the esophagus is important for the development and perpetuation of esophagitis, it is less well-recognized that in some patients there may be a primary gastric defect leading to hypersecretion of hydrochloric acid.

Johansson and colleagues (12) reported gastric hypersecretion in $66 \%$ of 100 patients referred to a surgical clinic with symptoms suggestive of GERD. Barlow et al (13) performed pentagastrinstimulated gastric secretory studies in 75 patients with abnormal esophageal exposure to gastric juice (proven by $24 \mathrm{~h}$ esophageal $\mathrm{pH}$ monitoring). Only those patients who had a basal acid output greater than $5.0 \mathrm{mmol} / \mathrm{h}$ and a maximal acid output greater than 30 $\mathrm{mmol} / \mathrm{h}$ were defined as 'hypersecretors'. Using this definition, $40 \%$ of GERD patients had an elevated basal acid output and $49 \%$ had an elevated maximum acid output, with $28 \%$ hav. ing both increased. In that study, a mechanically defective sphincter was defined as one with a lower esophageal sphincter pressure of $6 \mathrm{mmHg}$ or less, an overall length of less than $2.0 \mathrm{~cm}$ or an abdominal length of less than 1.0 $\mathrm{cm}$. Such a defect was present in 54 of the 75 patients (72\%) (Table 3). $\mathrm{Pa}$ tients with a mechanically normal sphincter had a greater prevalence of gastric hypersecretion than those with

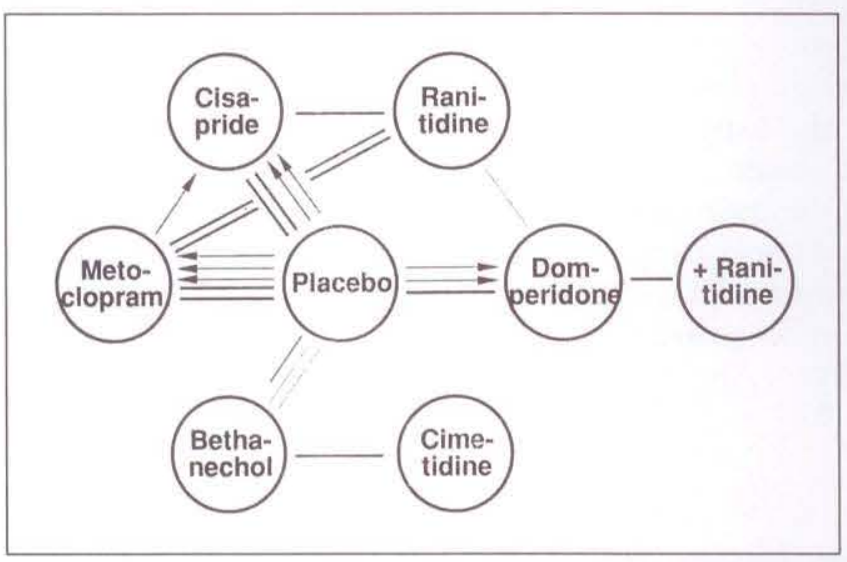

Figure 2) Results of randomized clinical trials showing efficacy of prokinetic drugs (metoclopramide, domperidone, bethanechol and cisapride) compared with other drugs and placebo in the management of reflux symptoms. Each connecting line (no significant difference in outcome) or arrow (significant difference in outcome pointing to the superior treatment) represents an individual study. (Adapted with permission from Koelz. Scand J Gastroenterol 1989;24[Suppl 156]:25-36)

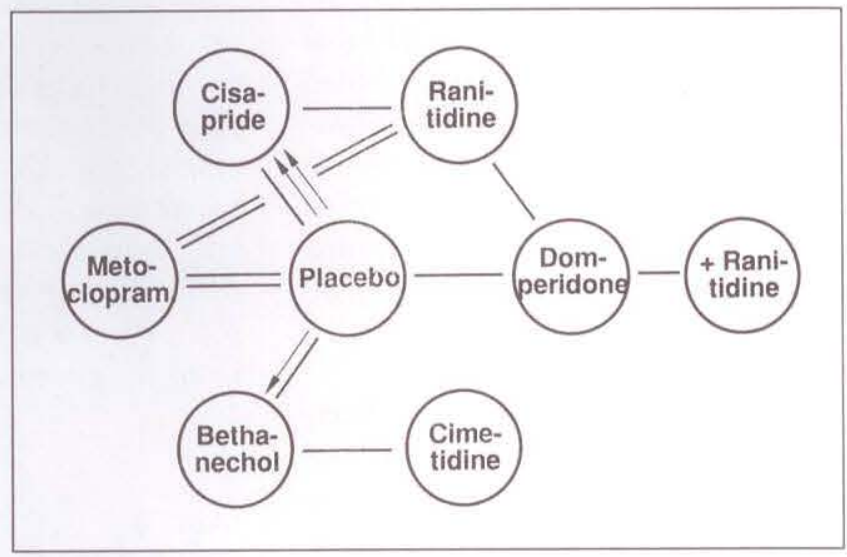

Figure 3) Results of randomized clinical trials efficacy of prokinetic drugs (metoclopramide, domperidone, bethanechol and cisapride) compared with other drugs and placebo in the healing of esophagitis. Each connecting line (no significant difference in outcome) or arrow (significant difference in outcome pointing to the superior treatment) represents an individual study. (Adapted with permission from Koelz. Scand J Gastroenterol 1989;24[Suppl 156]:25-36) 
a defective sphincter (48 versus $20 \%$, respectively, $\mathrm{P}<0.05$ ). Some patients had defects in both aggressive and defensive factors. In GERD patients with a normal lower esophageal sphincter pressure, 10 had gastric acid hypersecretion and 11 had normal secretion. In those with reduced low esophageal sphincter pressure, more had normal (versus increased) gastric acid secretion (about one patient in four). Thus, the role of gastric acid hypersecretion is important in all patients with GERD, but is perhaps even more important in those with a normal low esophageal sphincter pressure.

Collen et al (14) examined 23 patients with GERD, 11 of whom were 'responders' (ie, were asymptomatic after ranitidine $150 \mathrm{mg}$ bid for three months); the remaining 12 remained symptomatic and were termed 'non-responders'. Basal acid output and volume, and basal reflux time were greater in the nonresponders compared with responders. Interestingly, Barrett's epithelium was present in 10 of 12 nonresponders compared with only one of 11 responders - nine nonresponders had a basal acid output greater than 10 $\mathrm{mEq} / \mathrm{h}$ and gastric acid output had to be reduced below $1 \mathrm{mEq} / \mathrm{h}$ for symptoms of pyrosis to disappear. Thus, it would appear that both the defensive and aggressive portions of the imbalance equation are important in patients with GERD.

\section{THERAPY}

Principles and limitations: Simplistically, the therapeutic approach to the patient with GERD would be to reduce the aggressive and increase the defensive factors by reducing gastric acid secretion and enhancing esophageal and gastric motility. There is a long menu in fact a seven-course meal! - of therapeutic agents which may be used to treat patients with GERD. However, before considering these different therapeutic agents, as well as other lifestyle measures which may be effective in many patients, one must review a basic concept.

There are a number of tests of gastroesophageal reflux as well as ways to establish the presence of reflux damage.

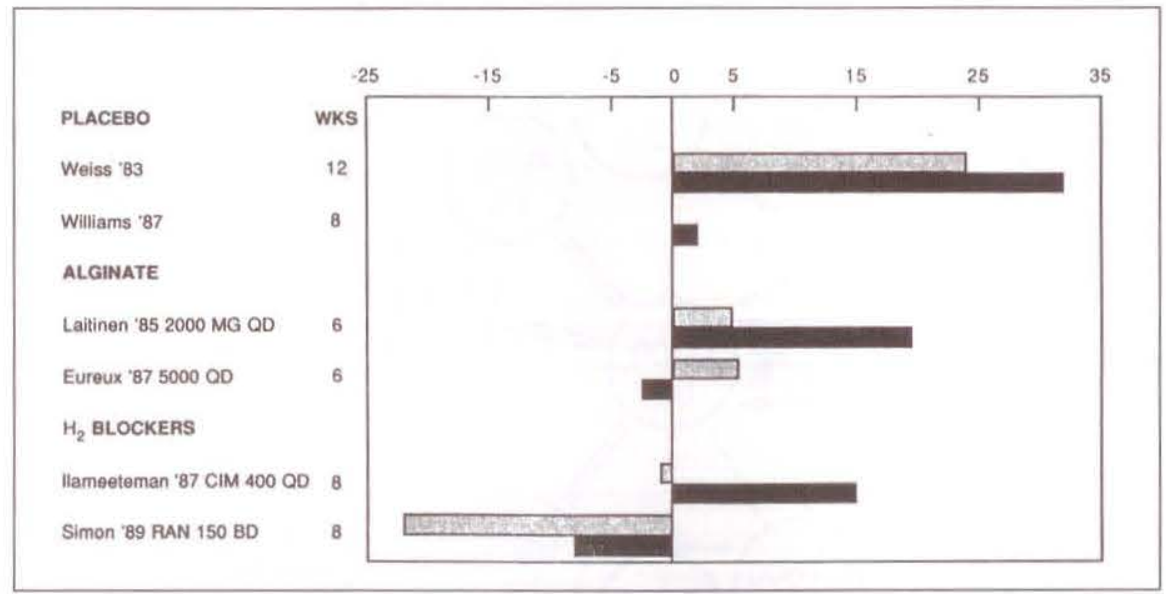

Figure 4) Therapeutic gain for treatment of moderately severe reflux esophagitis: sucralfate $1 \mathrm{~g}$ qid. (Adapted with permission from Tytgat et al. Scand J Gastroenterol 1990;25[Suppl 175]:1 12)

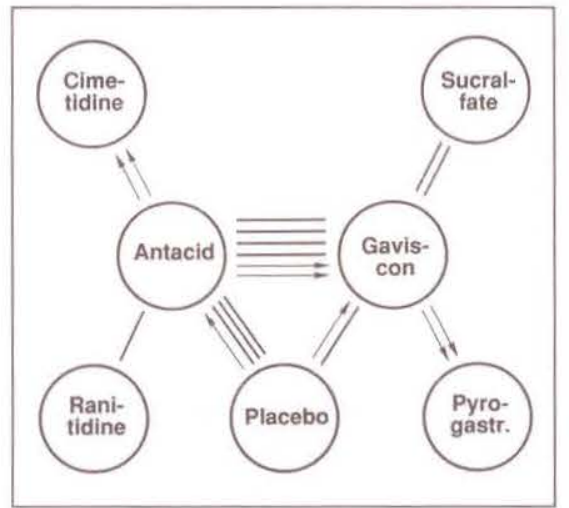

Figure 5) Results of randomized trials showing efficacy of antacids and alginate/antacid compared with other drugs and placebo in the management of reflux symptoms. Each connecting line (no significant difference in outcome) or arrow (significant difference in outcome pointing to the superior treatment) represents an individual study. (Adapted with permission from Koelz. Scand ] Gastroenterol 1989;24[Suppl 156]: 25-36)
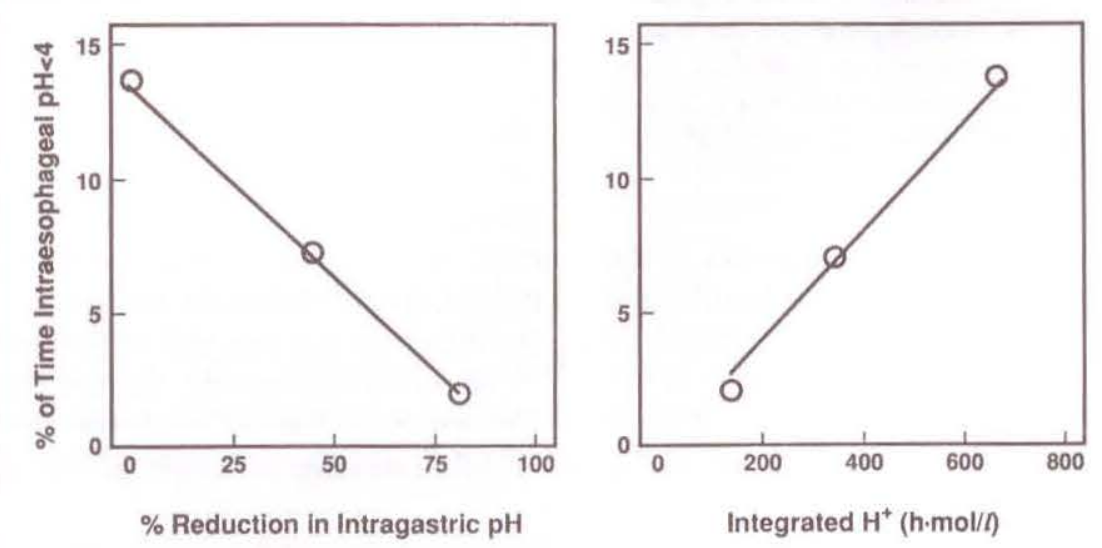

Figure 7) Effect of changes in gastric acidity on esophageal acid exposure. (Adapted with permission from Burget et al. Gastroenterology 1990;99:345-51)

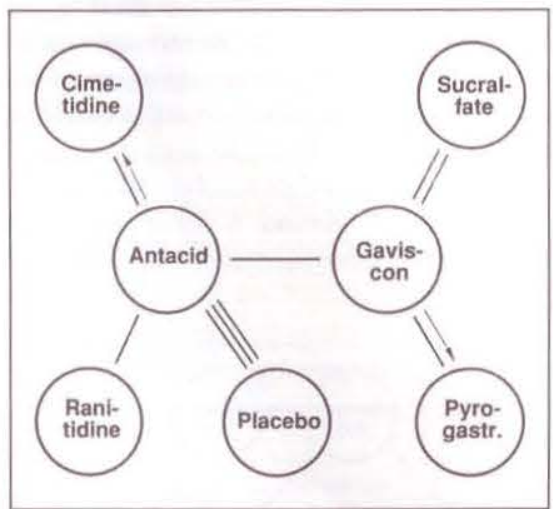

Figure 6) Results of randomized trials showing efficacy of antacids and alginatelantacid compared with other drugs and placebo in the healing of esophagitis. Each connecting line (no significant difference in outcome) or arrow (significant difference in outcome pointing to the superior treatment) represents an individual study. (Adapted with permission from Koelz. Scand J Gastroenterol 1989;24[Suppl 156]: 25-36) 


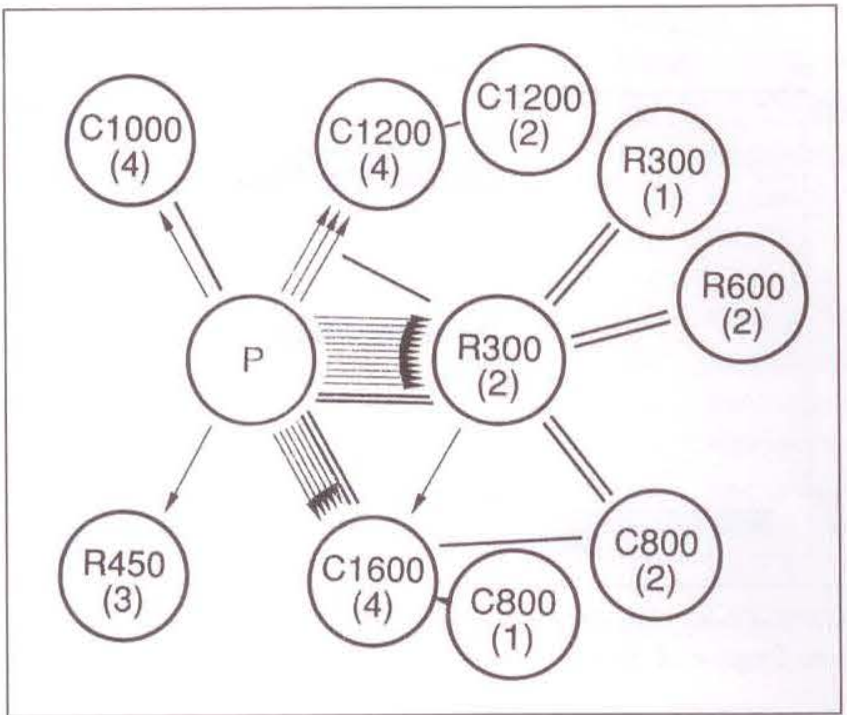

Figure 8) Results of randomized trials depicting efficacy of histamine $\mathrm{H}_{2}$-receptor antagonists in the management of reflux symptoms. Each connecting line (no significant difference in outcome) or arrow (significant difference in outcome pointing to the superior treatment) represents an individual study. Total daily amount (in $\mathrm{mg}$ ) of the drugs is given adjacent to the drug symbols and the number of daily doses is indicated in parentheses. C Cimetidine; P Placebo; $R$ Randitine. (Adapted with permission from Koelz. Scand J Gastroenterol 1989; 24[Suppl 156]:25-36)

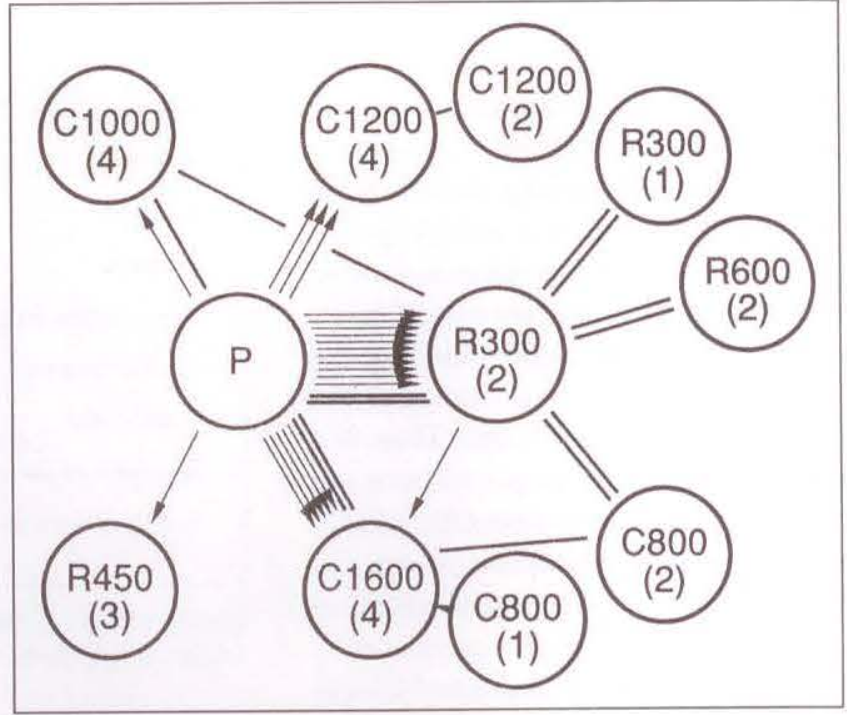

Figure 9) Efficacy of histamine $\mathrm{H}_{2}$-receptor antagonists in the healing of esophagitis. Results of randomized clinical trials are shown. Each connecting line (no significant difference in outcome) or arrow (significant difference in outcome pointing to the superior treatment) represents an individual study. (Adapted with permission from Koelz. Scand J Gastroenterol 1989;24[Suppl 156]:25-36)

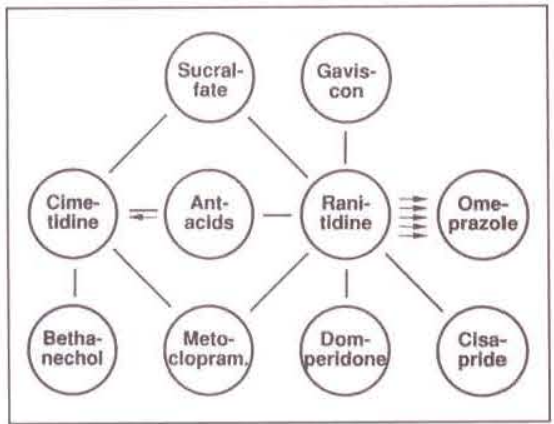

Figure 10) Results of randomized clinical trials depicting efficacy of histamine $\mathrm{H}_{2}$-receptor antagonists versus other drugs in the healing of reflux esophagitis. Results of randomized clinical trials. Each connecting line (no significant difference in outcome) or arrow (significant difference in outcome pointing to the superior treatment) represents an individual study. (Adapted with permission from Koelz. Scand J Gastroenterol 1989;24[Suppl 156]:25-36)

To the patient, and sometimes to the physician, the symptom of heartburn is equated with GERD. It is essential, however, to appreciate that GERD represents a spectrum of reflux damage varying from a normal appearing esophagus to one with severe ulcerative esophagitis. Based simply on the patient's symptoms, one can predict that gastroesophageal reflux has occurred, but severity of heartburn does not correlate with severity of the reflux, nor does the severity of heartburn correlate with the degree of reflux damage. Therapy, then, should focus not only on treatment of the patient's symptoms, but also (and importantly) on treatment of the esophagitis. Without endoscopy one cannot judge the degree of esophageal damage.

Tytgat and colleagues (15) have made an urgent plea for uniformity in the staging of reflux esophagitis. This is such a simple yet fundamental concept that in order to achieve an appropriate comparison of the literature regarding therapeutic efficacy of different drugs, one needs to know whether treatment is for a patient with symptoms but no esophageal damage, versus with symptoms and mild, moderate or severe esophagitis. Indeed, from the current literature it is difficult to achieve this important objective of comparing therapeutic efficacy on the basis of similar degrees of reflux damage or esophageal acid exposure. A classification scheme has been proposed with staging, varying from normal (Stage 0) to a mild erythema and friability (Stage I) to small superficial erosions covering only a small portion of the distal mucosal surface (Stage II) to confluent erosions and exudate covering less than onehalf of the distal mucosal surface (Stage III) to circumferential erosions with exudative lesions or deep ulceration and stricturing (Stage IV). Only when a definition system such as this has been adopted widely will it be possible to compare one therapeutic agent intelligently with another.

\section{LIFESTYLE CONSIDERATIONS}

Accepting these limitations, one must first consider lifestyle changes which may be useful as nondrug therapy in GERD. This involves consideration of food, gravity and the avoidance of certain drugs which may aggravate gastroesophageal reflux. The patient may be helped symptomatically by taking small, nonfatty meals, avoiding smoking and excess use of caffeine and alcohol, and working on a food-by-food basis to determine whether foods or beverages have any adverse effect on the patient's symptoms (Table 4 ). $\mathrm{Pa}$ tients will have less regurgitation and heartburn if they remain upright for at least $1 \mathrm{~h}$ after meals, avoid straining or 
wearing tight-fitting garments, focus their attention away from their esophagus and towards their waistline (achieve their ideal body weight) and elevate the head of their bed to reduce the frequency of reflux episodes occurring at night. There is great individual variation in just how much effect these measures will have on the patient's pain or on the healing of esophagitis. Nonetheless, these measures are simple, safe and economical, and should be followed as initial therapy in all patients with GERD.

\section{MEDICATIONS}

There is a long list of medications which may weaken the esophageal smooth muscle of the lower esophageal sphincter and overcome the normal defence factors against reflux (Table 5). It may not be possible for the patient to avoid these medications, and substituting other classes of drugs may not be appropriate. Some patients will not respond sufficiently well or quickly to these lifestyle changes and may require drug therapy for GERD. The three general classes of medication used in the drug therapy of GERD include prokinetic agents, mucosal coating compounds and antisecretory drugs $\left(\mathrm{H}_{2}\right.$-receptor blockers or pump blockers).

Promotility agents: The prokinetic agents have been reviewed recently (16). There is a growing list of indications for the use of prokinetic agents for patients with gastrointestinal disorders, including GERD, gastroparesis, post operative ileus, pseudo-obstruction and constipation. There are three groups of prokinetic agents: bethanechol (which has a direct cholinergic effect), metoclopramide and domperidone (which are antidopaminergic in action) and cisapride (which releases acetylcholine from the myenteric plexus and selectively stimulates the post ganglionic neurons of the myenteric plexus). Cisapride increases lower esophageal sphincter pressure, reduces gastroesophageal reflux and promotes gastric emptying (17-21). All these prokinetic agents will increase the lower esophageal sphincter pressure; cisapride also will effectively increase esophageal clearance of acid and accelerate gastric

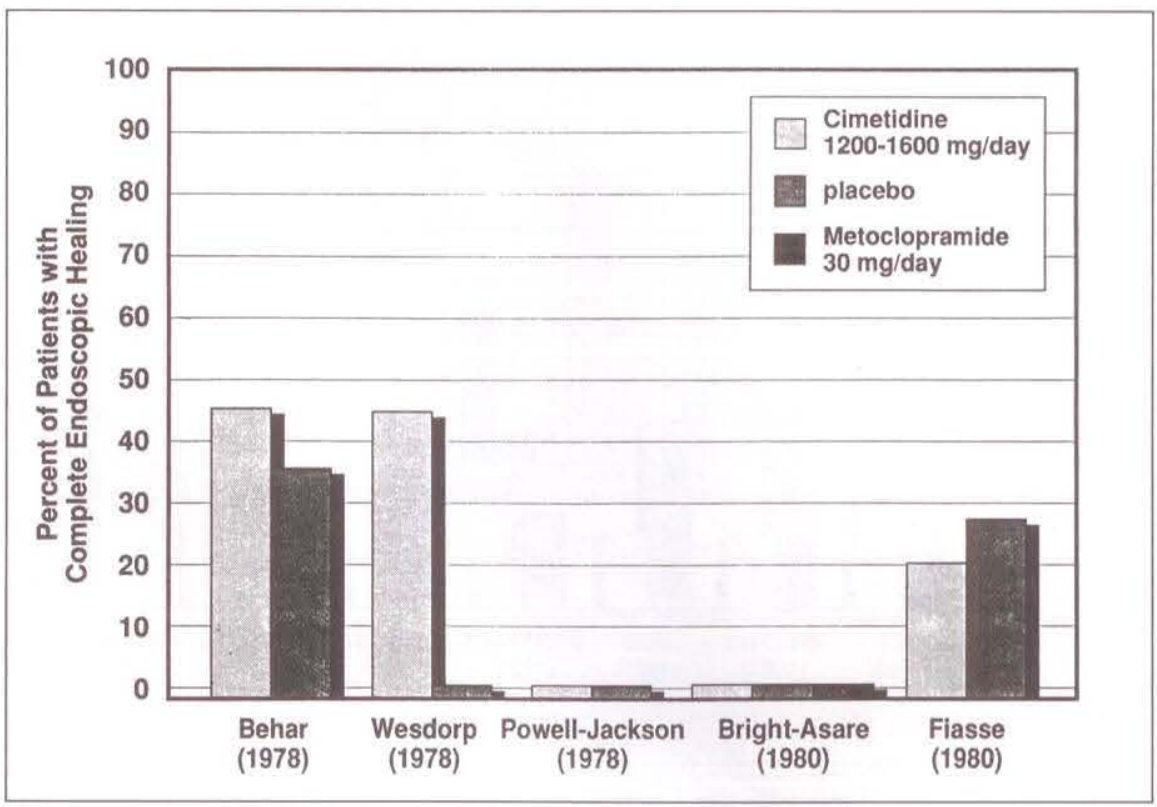

Figure 11) Reflux esophagitis healing rates with cimetidine at eight weeks. (Reprinted with permission from Sontag. Gastroenterol Clin North Am 1990;19:683-712)

$400 \times 4$ vs. $800 \times 2$

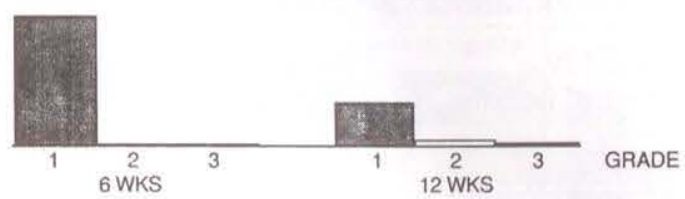

$400 \times 4$ vs. $800 \mathrm{HS}$

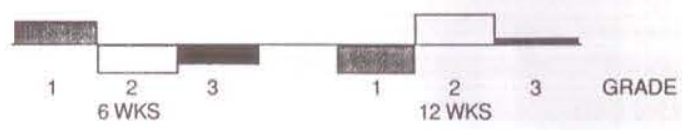

800 PM MEAL vs. 800 HS
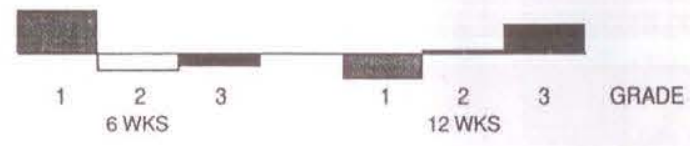

Figure 12) Therapeutic gain in endoscopic healing of grades 1 to 3 reflux esophagitis using different regimens of cimetidine. (Adapted with permission from Tytgat et al. Scand J Gastroenterol 1990;25[Suppl 175]:1-12)

emptying without any adverse effect on gastric acid secretion.

How effective are the promotility agents in treating patients with GERD? Cisapride $10 \mathrm{mg}$ qid before meals and at bedtime is superior to placebo and is as effective as ranitidine $150 \mathrm{mg}$ bid or cimetidine $400 \mathrm{mg}$ qid (Figure 1) in controlling reflux symptoms and in promoting the healing of reflux esophagitis (Figures 2,3) (22,23). Cisapride may be useful as combination therapy with cimetidine or ranitidine, and may provide effective maintenance therapy against recurrent GERD.
Is there a superior promotility agent? There is no clear answer to this question because no direct clinical comparison of cisapride against domperidone or metoclopramide exists. However, cisapride has an effective role in acid clearance, while such a role is less clear for domperidone or metoclopramide, so cisapride may prove to be the promotility agent of choice.

Antacids and suspensions of sulcrate: Mucosal-coating drugs, such as antacid, alginic acid or sucralfate (a suspension of aluminum hydroxide and a salt of sucrose octasulphate), are effective for 


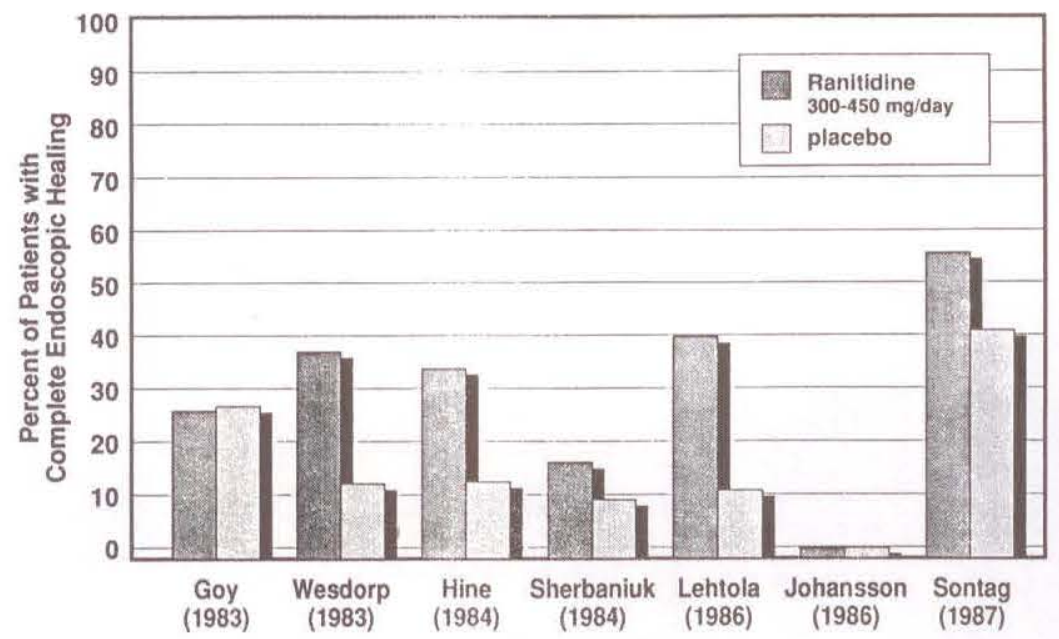

Figure 13) Reflux esophagitis healing rates with ranitidine at six to eight weeks. (Reprinted with permission from Sontag. Gastroenterol Clin North Am 1990;19:683-712)

\section{TABLE 6}

\section{Effects of ranitidine $300 \mathrm{mg} /$ day, $150 \mathrm{mg}$ bid and placebo on intragastric acidity and intraesophageal $\mathrm{pH}$}

\begin{tabular}{|c|c|c|c|}
\hline Variable $(24 \mathrm{~h})$ & Placebo & Ranilidine ( $150 \mathrm{mg}$ bid) & Ranitidine ( $300 \mathrm{mg}$ qid) \\
\hline $\begin{array}{l}\text { Integrated } \mathrm{H}^{+} \text {activity } \\
(h \cdot \mathrm{mol} / \mathrm{L})\end{array}$ & 674 (520 to 873$)$ & $349^{*}(270$ to 453$)$ & $132^{* \dagger}$ (100 to 174 ) \\
\hline $\begin{array}{l}\text { Reduction (\%) in } \\
\text { intragastric activity }\end{array}$ & - & $48.1(25.2$ to 64.0$)$ & $80.4(71.3$ to 86.6$)$ \\
\hline $\begin{array}{l}\text { Number of reflux } \\
\text { episodes }\end{array}$ & 122 (82 to 182$)$ & 81 (54 to 121$)$ & $30^{* \dagger}$ (19 to 47$)$ \\
\hline $\begin{array}{l}\text { Number of reflux } \\
\text { episodes longer } \\
\text { than } 5 \text { mins }\end{array}$ & $8.6(6.4$ to 11.5$)$ & $4.4^{*}(3.2$ to 6.1$)$ & $1.9^{* \dagger}(1.2$ to 3.1$)$ \\
\hline $\begin{array}{l}\text { Longest reflux } \\
\text { episode (mins) }\end{array}$ & $\begin{array}{c}28.6 \\
(18.0 \text { to } 45.4)\end{array}$ & $15.4(9.7$ to 24.4$)$ & $9.3^{*}$ (5.5 to 15.8$)$ \\
\hline $\begin{array}{l}\text { Time }(\%) \text { intra- } \\
\text { esophageal pH }<4\end{array}$ & $13.9(9.7$ to 20.0$)$ & $7.6(5.3$ to 10.9$)$ & $2.0^{* \dagger}(1.3$ to 3.0$)$ \\
\hline
\end{tabular}

- $P<0.01$ compared with placebo: ${ }^{t} P<0.01$ compared with ranitidine $150 \mathrm{mg}$ bid. (Reproduced with permission from Barlow et al. Arch Surg 1989:124:937-40)

treating patient symptoms and for healing associated esophagitis (Figures 4-6). If the patient's symptoms persist despite use of antacids, they should consult their physician; the patient and physician may then choose to use promotility or antisecretory agents.

Antisecretory agents: There is a correlation between the daily ranitidine dose required to eliminate symptoms of pyrosis and the pretreatment basal acid output (14). Is there a degree of gastric acid inhibition that will reduce intraesophageal $\mathrm{pH}$ sufficiently to allow healing of esophagitis achieved by therapy to be predicted? Such a relationship has been described for patients with duodenal ulcers (24). What, then, is the relationship between intragastric and intraesophageal $\mathrm{pHs}$, and between intraesophageal $\mathrm{pH}$ and healing of GERD? Seventeen patients with moderate to severe esophagitis had three $\mathrm{pH}$-metric studies in a cross-over design before and after eight days of treatment with omeprazole $20 \mathrm{mg}$ od or ranitidine $300 \mathrm{mg}$ bid (25). Intragastric acidity fell from $84.0 \mathrm{mmol} / \mathrm{L}$ in the basal study to 14.2 $\mathrm{mmol} / \mathrm{L}$ ( $79 \%$ inhibition) with ranitidine and $9.3 \mathrm{mmol} / \mathrm{L}$ ( $84 \%$ inhibition) with omeprazole. In addition, median hourly $24 \mathrm{~h}$ intragastric $\mathrm{pH}$ was 1.8 in the basal study, 2.9 after ranitidine and 3.4 after omeprazole. What is new and important in this study is the observation that the time with esophageal $\mathrm{pH}$ less than 4 dropped significantly from $23.9 \%$ in the basal study to $8.5 \%$ with ranitidine and to $7.2 \%$ with omeprazole. Both drugs reduced esophageal exposure to acid in both the supine and upright positions, but neither had any effect on esophageal acid clearance. Using the data of Barlow et al (26), it is possible to show a linear relationship between the percentage reduction in intragastric $\mathrm{pH}$ and the percentage of time over $24 \mathrm{~h}$ when the intraesophageal $\mathrm{pH}$ was less than 4 (Figure 7, left panel). Similarly, as the integrated hydrogen ion activity $(\mathrm{h} \cdot \mathrm{mol} / \mathrm{L})$ was increased, there was also an increase in the percentage of time the intraesophageal $\mathrm{pH}$ exceeded 4 (Figure 7, right panel). Thus, the reduction in intragastric $\mathrm{pH}$ is associated with, as expected, a decline in intraesophageal $\mathrm{pH}$. However, how much reduction in hydrogen ion concentration in the esophagus (or stomach) is necessary to achieve acute healing or to provide effective maintenance of healing is unknown.

There are two broad classes of antisecretory agents: the $\mathrm{H}_{2}$-receptor antagonists and $\mathrm{H}^{+}, \mathrm{K}^{+}$-ATPase inhibitors (the 'pump blockers'). There are a number of $\mathrm{H}_{2}$-receptor antagonists, including cimetidine, ranitidine, famotidine and nizatidine, available for use in countries worldwide. The $\mathrm{H}_{2}$-receptor antagonists do not have an effect on the lower esophageal sphincter pressure and do not modify esophageal acid clearance (27), but may reduce the number of reflux episodes, resulting in fewer and shorter reflux episodes. Accepting the limitations of the lack of stratification for the severity of esophagitis in most clinical trials addressing the use of $\mathrm{H}_{2}$-blockers in GERD, there is an apparent general consensus that these drugs are useful in short term use and in 'conventional' doses (ie, those doses usually used to treat patients with duodenal ulcer disease) for the treatment of mild to moderately severe esophagitis. There is generally good symptom relief, although usually less than one-half of patients will 


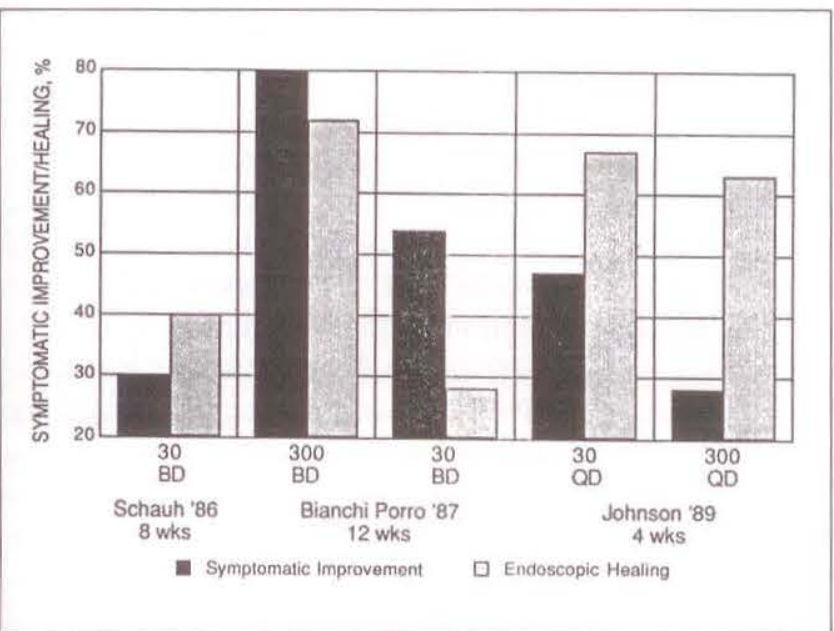

Figure 14) Ranitidine $150 \mathrm{mg}$ bid versus $300 \mathrm{mg}$ bid or qid in treatment of symptoms of reflux esophagitis. (Adapted with permission from Tytgat et al. Scand J Gastroenterol 1990;24[Suppl175]:1-12)

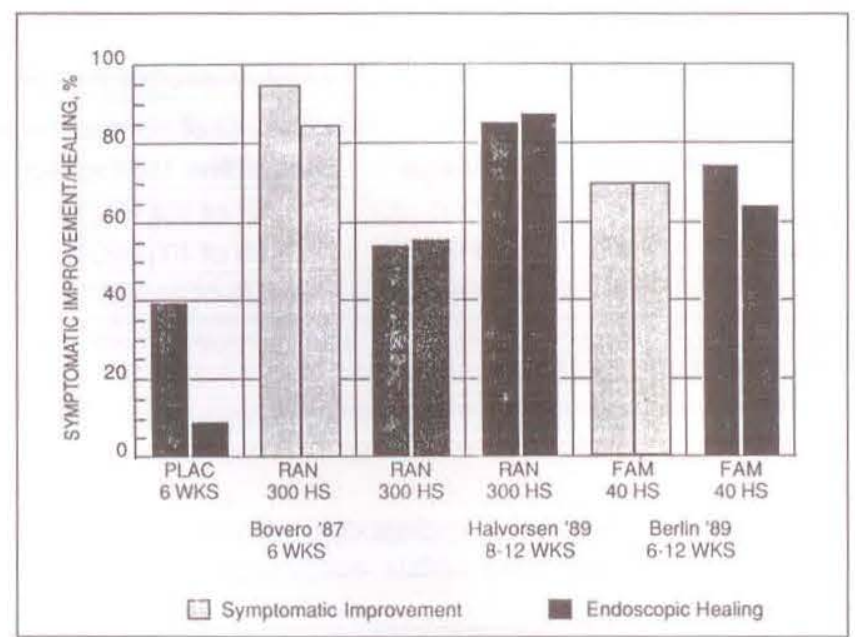

Figure 15) Refluxesophagitis: $\mathrm{H}_{2}$-receptor antagonists and symptomatic improvement. (Adapted with permission from Tytgat et al. Scand J Gastroenterol 1990;25[Suppl 175]:1-12) achieve endoscopic healing with the $\mathrm{H}_{2}$-receptor antagonists (Figures 8-10). Because these agents are used so widely to treat patients with GERD, one should consider their individual performance. Cimetidine: Three of 10 studies of the effect of cimetidine 1000 to 1600 $\mathrm{mg} / \mathrm{day}$ for six to 26 weeks have shown statistically significant improvement in the endoscopic grade of esophagitis compared with placebo (28-37), but the endoscopic healing rates are variable and generally low (Figure 11). Doses of 800 to $1600 \mathrm{mg}$ daily are comparable in terms of achieving healing (38). Various dosing regimens are approximately comparable (Figure 12); for example, $600 \mathrm{mg}$ bid and $300 \mathrm{mg}$ qid are comparable (39).

Nizatidine: Nizatidine $300 \mathrm{mg}$ at night is not useful to treat patients with GERD, yet $150 \mathrm{mg}$ bid is superior to placebo in reducing esophagitis (40). At a high dose of $300 \mathrm{mg}$ bid, 12-week healing rates were $50 \%$ compared with $34 \%$ with placebo (41); a further study has confirmed the superiority of nizatidine given twice (rather than once) a day (42).

Ranitidine: Ranitidine reduces esophageal acid contact time, reflux episode, frequency and heartburn frequency and severity in patients with GERD (43). Compared with placebo, ranitidine 300 to $450 \mathrm{mg} /$ day for six to eight weeks was associated with significant endoscopic healing in six of nine studies (44-52), but endoscopic healing was usually

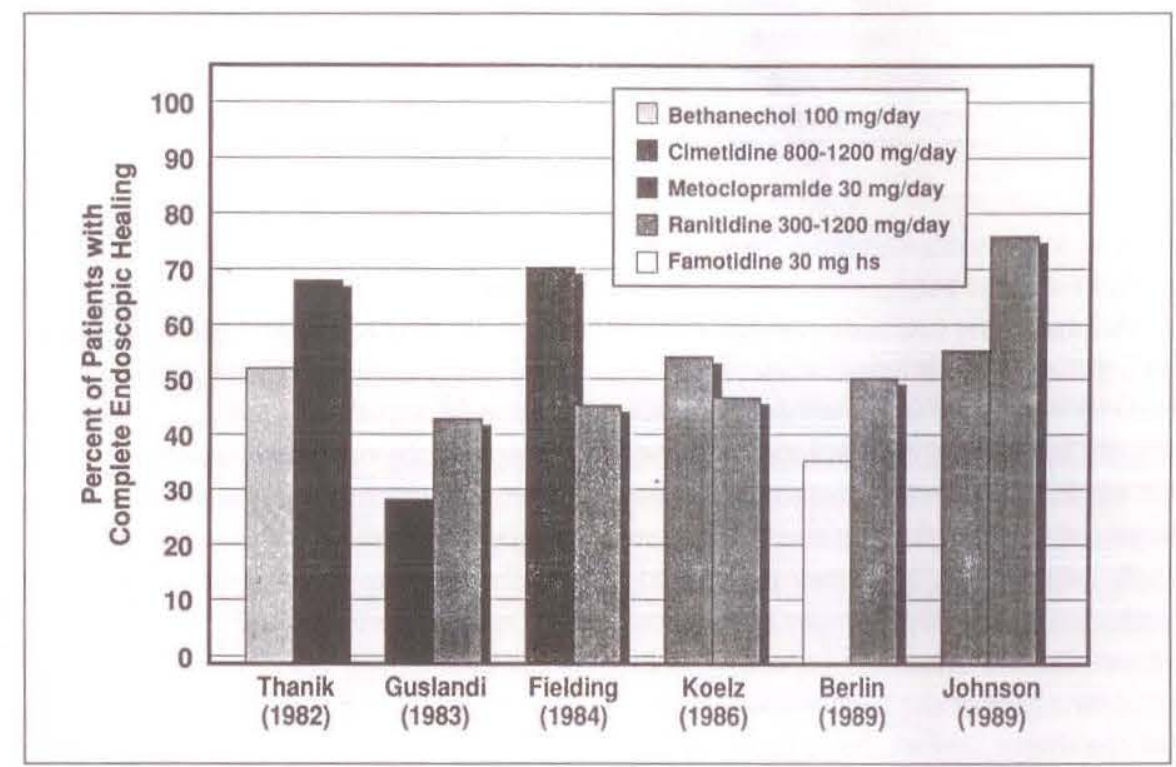

Figure 16) Reflux esophagitis healing rates with $\mathrm{H}_{2}$-receptor antagonists and prokinetics used for six to eight weeks. (Reprinted with permission from Sontag. Gastroenterol Clin North Am $1990 ; 19: 683-712)$

achieved in less than one-half of patients (Figure 13).

Will higher doses of ranitidine prove to be more useful in patients with GERD, compared with 'standard' doses used to treat patients with peptic ulcer disease? Barlow et al (26) performed simultaneous $24 \mathrm{~h}$ monitoring of intragastric and intraesophageal $\mathrm{pH}$ in 12 patients with endoscopically proven erosive reflux esophagitis. With increasing doses of ranitidine from 150 $\mathrm{mg}$ bid to $300 \mathrm{mg}$ qid, the integrated hydrogen ion activity $(\mathrm{h} \cdot \mathrm{mol} / \mathrm{L})$ fell, with a reduction of intragastric $\mathrm{pH}$ of
48.1 and $80.4 \%$, respectively (Table 6). Higher doses are not always more effective than the standard dose of ranitidine $150 \mathrm{mg}$ bid (Figure 14), but higher doses given at bedtime may give higher rates of symptomatic improvement and endoscopic healing (Figures 15 and 16). Two studies have shown that ranitidine $300 \mathrm{mg}$ at bedtime is as good as $150 \mathrm{mg}$ bid $(53,54)$, and while increasing the dose to $300 \mathrm{mg}$ bid was without benefit (55), increasing the dose from $150 \mathrm{mg}$ bid to $300 \mathrm{mg}$ qid did significantly improve the healing of moderately severe esophagitis (from 29 to 
TABLE 7

Effects of ranitidine 150 and $300 \mathrm{mg}$ qid, and placebo on erosive esophagitis

\begin{tabular}{lccc}
\hline $\begin{array}{l}\text { Number of weeks } \\
\text { before healing }\end{array}$ & \multicolumn{3}{c}{$\begin{array}{c}\text { Number (\%) of patients healed by: } \\
\text { Ranitidine } \mathbf{1 5 0} \text { mg qid }\end{array}$} \\
\hline Rantidine 300 mg qid \\
\hline Three & 21 of $103(20)$ & 47 of $104(45)^{*}$ & 50 of $109(46)^{*}$ \\
11 & 30 of $92(33)$ & 68 of $100(68)^{*}$ & 73 of $105(70)^{*}$ \\
\hline
\end{tabular}

- $P<0.01$ versus placebo. (Reproduced with permission from Euler et al. Gastroenterology 1991:100:A161)

\section{TABLE 8}

Healing of esophagitis at endoscopy with famotidine $20 \mathrm{mg}$ bid versus $40 \mathrm{mg}$ bid in erosive/ulcerative reflux esophagitis; presented as number healed/ number assessed

\begin{tabular}{lcccccc}
\hline & \multicolumn{2}{c}{ Week 6} & \multicolumn{2}{c}{ Week 12} & \multicolumn{2}{c}{ Week 24} \\
Grade & $20 \mathrm{mg}$ & $40 \mathrm{mg}$ & $20 \mathrm{mg}$ & $\mathbf{4 0} \mathrm{mg}$ & $20 \mathrm{mg}^{*}$ & $40 \mathrm{mg}$ \\
\hline I & 43 of 76 & 57 of 80 & 59 of $73^{\dagger}$ & 68 of $78^{\dagger}$ & 63 of 73 & 69 of 78 \\
II & 41 of 94 & 56 of $92^{*}$ & 68 of $91^{\dagger}$ & 68 of 92 & 73 of 91 & 74 of 92 \\
III & 10 of 39 & 15 of 38 & 14 of 37 & 25 of $37^{* \dagger}$ & 21 of 37 & 28 of 37 \\
IV & 0 of 11 & 2 of 13 & 0 of 9 & 6 of $13^{\dagger}$ & 1 of 9 & 8 of $13^{*}$ \\
All & 94 of 220 & 130 of $223^{*}$ & 142 of $210^{\dagger}$ & 167 of $220^{\dagger}$ & 158 of 210 & 179 of 220 \\
\hline
\end{tabular}

${ }^{*} P<0.05$ versus $20 \mathrm{mg}^{\dagger}{ }^{\dagger}<<0.05$ versus week $6 ;{ }^{*} 40 \mathrm{mg}$ bid from weeks 12 to 24 . (Reproduced with permission from Festen et al. Gastroenterology 1991:100:A63)

$63 \%$ at four weeks and from 54 to $75 \%$ at eight weeks) (56).

A large study has been conducted in 342 patients with erosive esophagitis treated with placebo or ranitidine 150 $\mathrm{mg}$ qid or $300 \mathrm{mg}$ qid for four, eight or 12 weeks (57). Both ranitidine groups were superior to placebo and similar to each other. Healing rates progressed with time (Table 7); because the grades of esophagitis were not reported, it is unclear whether the higher dose of ranitidine might, in fact, have been superior if just grade III/IV patients had been examined, as was the case in the study by Festen and colleagues (58). Thus, 12 -week healing rates with higher doses of ranitidine are good, but the total daily dose may not need to be increased beyond $600 \mathrm{mg}$.

How does ranitidine compare with other agents used for the treatment of GERD? After eight weeks of therapy in a small number of patients, ranitidine $150 \mathrm{mg}$ bid and cimetidine $400 \mathrm{mg}$ bid were equivalent (59), with ranitidine $150 \mathrm{mg}$ bid superior to metoclopramide $10 \mathrm{mg}$ tid (60) but equivalent to cisapride $10 \mathrm{mg}$ qid (22).

Famotidine: Famotidine $40 \mathrm{mg}$ at night heals $82 \%$ of patients with mild esophagitis (61). Famotidine $40 \mathrm{mg}$ bid heals $48 \%$ of patients with moderate to severe esophagitis at six weeks compared with $18 \%$ with placebo (healing rates increasing to 69 and $29 \%$ at 12 weeks) (62). Twelve-week healing rates with famotidine $20 \mathrm{mg}$ bid were $54 \%$. Famotidine $40 \mathrm{mg}$ at bedtime is effective in the symptomatic and endoscopic improvement of patients with GERD (Figure 15). Furthermore, two recent large multicentre studies $(62,63)$ in patients with active erosive esophagitis showed that famotidine $20 \mathrm{mg}$ bid and $40 \mathrm{mg}$ bid are clinically effective in promoting healing of esophageal erosion or ulceration and relieving symptoms. In a large American study (64) comparing famotidine $20 \mathrm{mg}$ bid with $40 \mathrm{mg}$ at bedtime, both doses of famotidine were superior to placebo, and twice-daily dosing was superior for total relief of daytime heartburn. Festen et al (58) studied famotidine $20 \mathrm{mg}$ bid and $40 \mathrm{mg}$ bid at six, 12 and 24 weeks in 474 patients with grades I to IV esophagitis. Famotidine $40 \mathrm{mg}$ bid was more effective and achieved faster healing than did $20 \mathrm{mg}$ bid (Table 8 ), with the difference between the low and high dose being more marked with the increasingly severe degree of esophagitis. In addition, 12-week treatment was more effective than six-week, but extending treatment to 24 weeks had no significant additional effect. Thus, famotidine $40 \mathrm{mg}$ bid for 12 weeks represents effective therapy for GERD.

What are the comparative healing

\section{TABLE 9}

$24 \mathrm{~h}$ reflux variables before and after treatment with famotidine or ranitidine

\begin{tabular}{|c|c|c|c|c|}
\hline & \multicolumn{4}{|c|}{ Patients with GERD } \\
\hline & Basal & Famotidine & Ranitidine & Control \\
\hline Total time $\mathrm{pH}<4$ & $228(55 \text { to } 388)^{*}$ & $72.3(6 \text { to } 138)^{* *}$ & $84.6(12 \text { to } 181)^{* * *}$ & $44.5(4$ to 66$)$ \\
\hline Total & $17.6(4 \text { to } 40)^{*}$ & $5.7(1.3 \text { to } 10.2)^{* *}$ & $8.2(0.9 \text { to } 15.8)^{* *}$ & $3.4(0.5$ to 4.9$)$ \\
\hline Upright & $18.7(3.5 \text { to } 38)^{*}$ & $8.5(1 \text { to } 17.2)^{* *}$ & $12.5(1.5 \text { to } 21.1)^{*}$ & 2.8 (1.05 to 6.65$)$ \\
\hline Supine & $17.2(1.2 \text { to } 39)^{*}$ & $2.1(0.5 \text { to } 4.7)^{* *}$ & $3.5(1 \text { to } 6.3)^{* *}$ & $2.2(0$ to 5.3$)$ \\
\hline Number of reflux episodes & 63.5 (40 to 142$)$ & 59.1 (10 to 108$)$ & $67(15$ to 146$)$ & 35.5 ( 11 to 96$)$ \\
\hline Longest reflux episode (mins) & 55 (5 to 58.5$)$ & $15(1$ to 34$)$ & $39(4$ to 48$)$ & $2(1$ to 13$)$ \\
\hline Clearance times (mins) & $1.3(0.68$ to 3.22$)$ & $1.4(0.3$ to 4.2$)$ & $1.2(0.4$ to 3.9$)$ & $1.26(0.4$ to 3$)$ \\
\hline
\end{tabular}

- $P<0.01$ versus control; "*P<0.01 versus basal. (Reproduced with permission from Fiorucci et al. Scand J Gastroenterol 1989:24:671-7) 


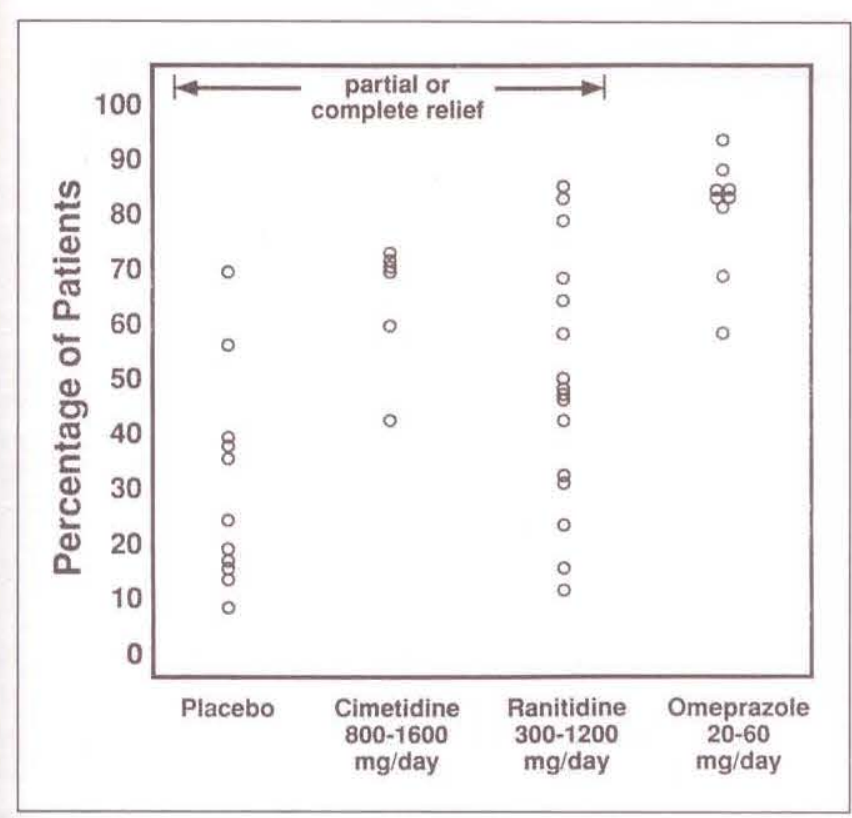

Figure 17) Reflux symptoms at six to eight weeks in patients treated with placebo, cimetidine, ranitidine or omeprazole. (Reprinted with permission from Sontag. Gastroenterol Clin North Am 1990;19:683-712)

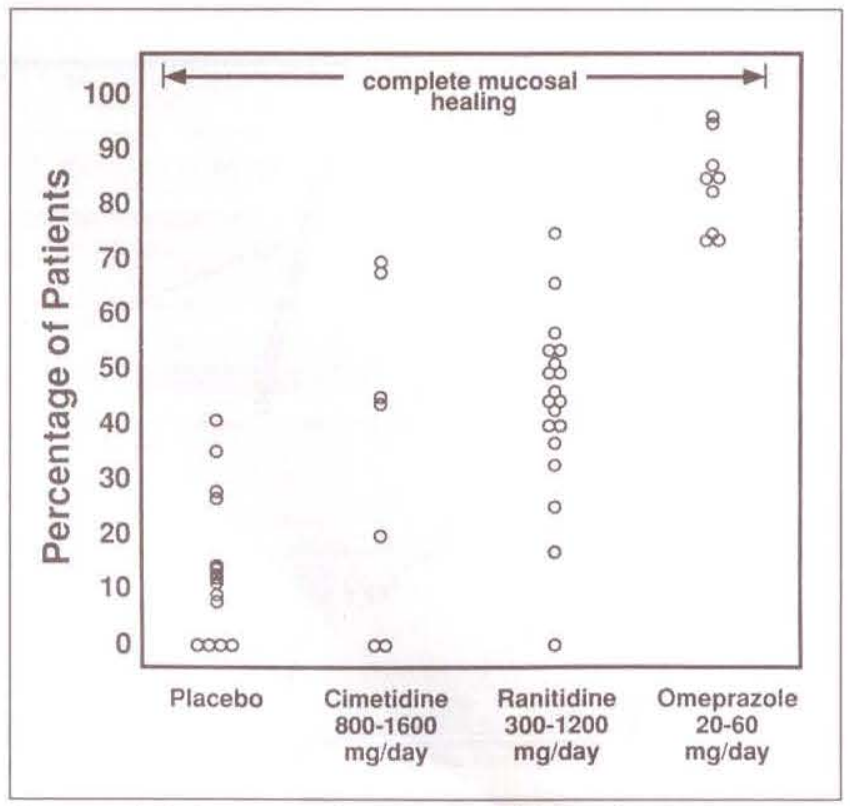

Figure 18) Endoscopic esophagitis at six to eight weeks in patients treated with placebo, cimetidine, ranitidine or omeprazole. (Reprinted with permission from Sontag. Gastroenterol Clin North Am 1990;19:683-712)

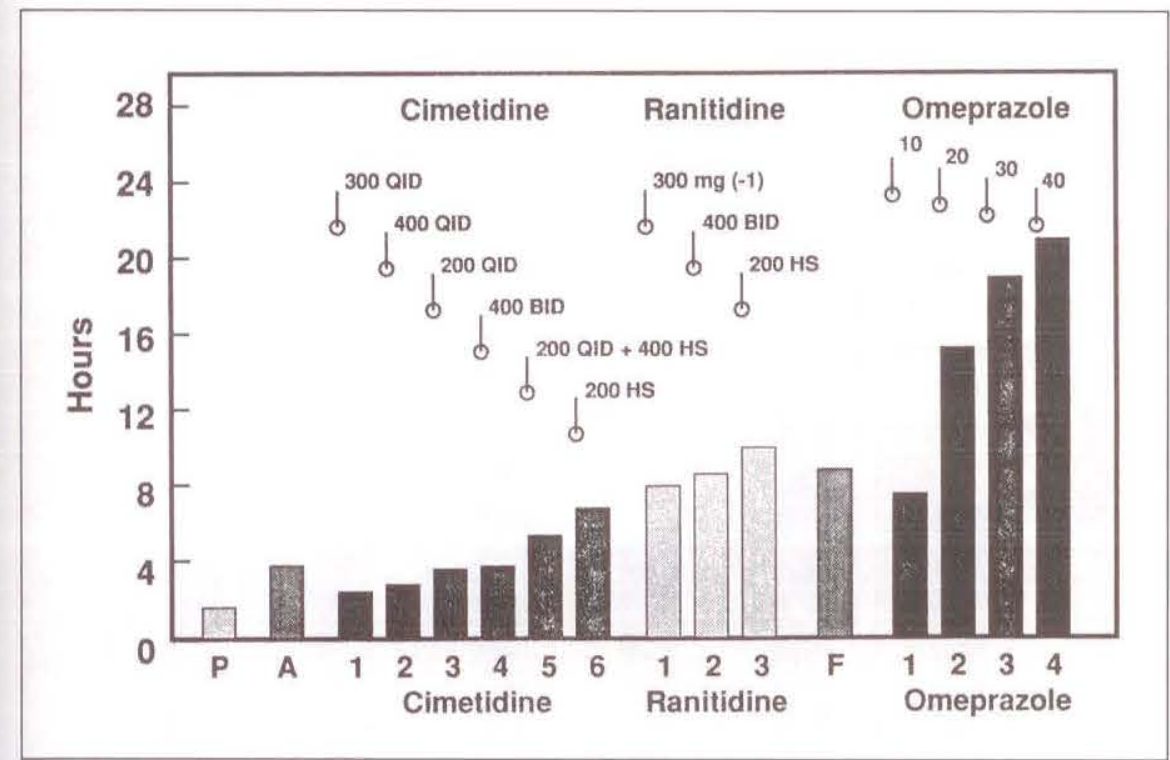

Figure 19) Hours of a 24 h day during which intragastric $p H$ was at least 4 . (Adapted with permission from Burget et al. Gasteroenterology 1990;99:345-51)

rates of these four $\mathrm{H}_{2}$-receptor blockers? Ranitidine $150 \mathrm{mg}$ bid and cimetidine $400 \mathrm{mg}$ bid are equivalent (59). Fiorucci et al (27) demonstrated - in 19 patients with moderate esophagitis - that famotidine $40 \mathrm{mg}$ and ranitidine $300 \mathrm{mg}$ taken at 20:00 after the evening meal have comparative efficacy in changing reflux variables. Acid reflux was defined as a drop in esophageal $\mathrm{pH}$ to below 4 , and reflux duration was defined as the time re- quired for the $\mathrm{pH}$ to return to above 4 $(65,66)$. Both ranitidine and famotidine significantly reduced the total time that the intraesophageal $\mathrm{pH}$ was less than $4-$ in both the supine and the upright positions - without influencing the number of reflux episodes lasting longer than 5 mins, the number of reflux episodes, the duration of the longest reflux episode or the acid clearance time (Table 9). Nighttime dosing was effective at nighttime but

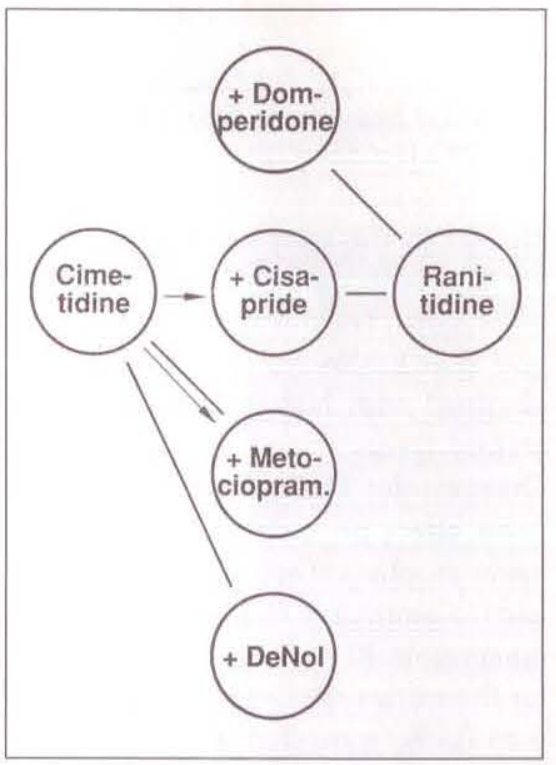

Figure 20) Results of randomized clinical trials depicting efficacy of histamine $\mathrm{H}_{2}$-receptor antagonists with and without additional prokinetic drugs or colloidal bismuth in the healing of reflux esophagitis. Each connecting line (no significant difference in outcome) or arrow (significant difference in outcome pointing to the superior treatment) represents an individual study. (Adapted with permission from Koelz. Scand J Gastroenterol 1989;24[Suppl 156]:25-36)

did not extend into daytime.

It remains unclear, however, whether one $\mathrm{H}_{2}$-receptor antagonist, given in the equivalent acid-inhibitory doses, is any better than another $\mathrm{H}_{2}$ 


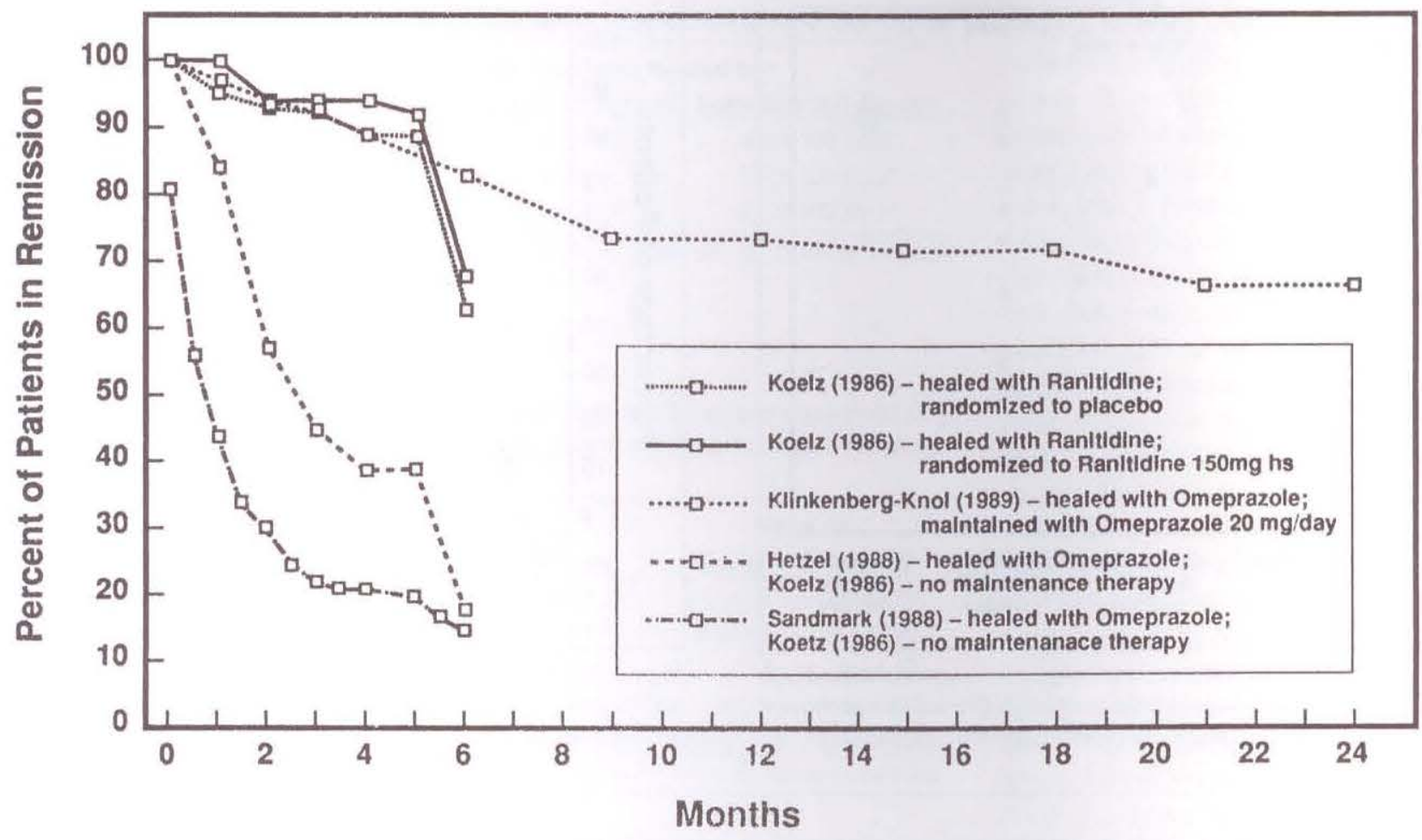

Figure 21) Maintenance therapy in patients with gastroesophageal reflux disease. (Reprinted with permission from Sontag. Gastroenterol Clin North Am 1990;19:6834-712)

blocker in the symptomatic treatment of GERD or in the healing of associated esophagitis, but the available data support that healing rates of $50 \%$ can be obtained with higher doses of antisecretory agents.

Omeprazole: Omeprazole has no adverse effect on esophageal peristalsis, lower esophageal sphincter pressure or gastric emptying $(67,68)$. A dose of omeprazole $40 \mathrm{mg}$ od reduces the time for the intraesophageal $\mathrm{pH}$ to be below 4 to $0.7 \%$, compared with $3.1 \%$ with omeprazole $20 \mathrm{mg}$ od (69). This $20 \mathrm{mg}$ dose of omeprazole reduces intraesophageal $\mathrm{pH}$ parameters more than does ranitidine (70). Omeprazole $20 \mathrm{mg}$ maintains intragastric $\mathrm{pH}$ greater than 4 for about 16 h each day, whereas most doses of $\mathrm{H}_{2}$-receptor antagonists maintain this level for about only $10 \mathrm{~h}$ each day (24). Why is this $\mathrm{pH}$ value of interest? It is thought that intraesophageal $\mathrm{pH}$ must be kept above at least 4 in order to prevent esophageal acid-induced damage.

The $\mathrm{H}^{+}, \mathrm{K}^{+}$-ATPase inhibitors (the 'pump blockers') may provide for higher rates of symptom relief of GERD

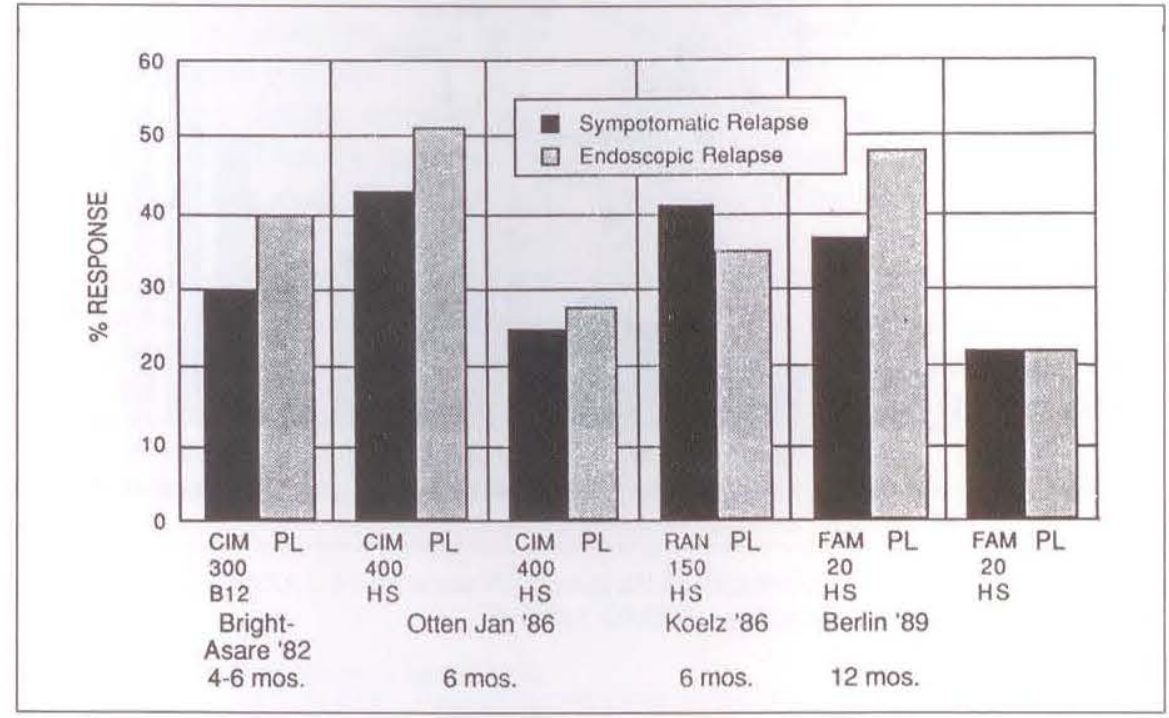

Figure 22) Placebo-controlled trials of maintenance therapy in patients with reflux esophagitis. (Adapted with permission from Tytgat et al. Scand J Gastroenterol 1990;25[Suppl 175]:1-12)

and endoscopic healing of esophagitis than do the $\mathrm{H}_{2}$-receptor antagonists. For example, symptom relief and endoscopic healing after six to eight weeks of treatment is greater with omeprazole than with cimetidine or ranitidine (Figures 17,18). With standard doses of $\mathrm{H}_{2}$-blockers, approximately
$30 \%$ of patients heal their esophagitis in 12 weeks compared with approximately $80 \%$ of patients treated with doses of omeprazole varying from 20 to $80 \mathrm{mg}$ daily.

Eight studies have shown superior healing rates of moderate to severe esophagitis of any grade with omeprazole 
20 to $60 \mathrm{mg}$ daily compared with ranitidine (70-77) or cimetidine (78). For example, in a double-blind randomized study comparing omeprazole $20 \mathrm{mg}$ given once daily and ranitidine $150 \mathrm{mg}$ bid in 152 patients with endoscopically verified erosive and/or ulcerative esophagitis, the four-week healing rates were $67 \%$ in the omeprazole group and $31 \%$ in the ranitidine group $(\mathrm{P}<0.0001)$, with rates of $85 \%$ and $50 \%$, respectively, after eight weeks of treatment $(\mathrm{P}<0.0001)$ (74). The proportion of patients with grades 2 to 4 esophagitis pre-entry were similar. Numerous other studies have also shown faster and more substantial healing as well as improvement in reflux symptoms compared with ranitidine (personal communication) (79-83). A meta-analysis (84) of three trials comparing omeprazole $150 \mathrm{mg}$ bid $(73,74,79)$ demonstrated an approximately $30 \%$ greater healing rate for omeprazole compared with ranitidine at weeks 4 and 8 of treatment. A comparable superiority of omeprazole $20 \mathrm{mg}$ has been reported compared with cimetidine $400 \mathrm{mg}$ bid (83).

An understanding of the reason for these differences in clinical efficacy may be obtained from an examination of the relative efficacy of the various $\mathrm{H}_{2}$ blockers and omeprazole on $24 \mathrm{~h}$ intragastric acidity (Figure 19); increasing the dose of $\mathrm{H}_{2}$-blockers has a relatively modest effect on prolonging the number of hours that the intragastric $\mathrm{pH}$ is 4.0 or above, whereas increasing the dose of omeprazole has a much greater effect. It must be stressed, however, that it is unclear what threshold is required for the time to maintain the intraesophageal $\mathrm{pH}$ at at least 4 to achieve healing of a given severity of endoscopically demonstrated esophagitis.

Omeprazole may also be effective to treat peptic esophageal strictures (85), to achieve regression of columnar epithelium in GERD patients with Barrett's epithelium (86) and to treat erosive esophagitis refractory to high dose cimetidine or ranitidine $(87,88)$. Better healing rates are obtained for milder esophagitis or for longer periods of therapy. Ambulatory $24 \mathrm{~h}$ esophageal $\mathrm{pH}$ measurements have been performed in

TABLE 10

Famotidine $\mathbf{2 0}$ and $\mathbf{4 0} \mathrm{mg}$ bid as maintenance therapy with healed erosive esophagitis

\begin{tabular}{|c|c|c|c|}
\hline \multicolumn{4}{|c|}{ Relapse of erosive esophagitis ${ }^{\dagger}$} \\
\hline Time period & $20 \mathrm{mg}$ bid $(n=69)$ & $40 \mathrm{mg}$ bid $(n=72)$ & Placebo $(n=31)$ \\
\hline Month 3 & $15.6^{* *}$ & $7.5^{*}$ & 44.4 \\
\hline Month 6 & $33.7^{*}$ & $21.9^{* *}$ & 66.6 \\
\hline \multicolumn{4}{|c|}{ Prevention of global symptomatic deterioration ${ }^{*}$} \\
\hline Time period & $20 \mathrm{mg}$ bid $(n=69)$ & $40 \mathrm{mg}$ bid $(n=72)$ & Placebo $(n=31)$ \\
\hline Month 3 & $76.8^{* *}$ & $76.4^{* *}$ & 58.1 \\
\hline Month 6 & $62.3^{* *}$ & $70.8^{* *}$ & 29.0 \\
\hline
\end{tabular}

"P<0.05: " $P<0.01$ versus placebo: ${ }^{\dagger}$ Relapse defined as recurrence of endoscopically verified erosive esophagitis; ${ }^{\dagger}$ Prevention defined as no or slight deterioration

TABLE 11

Famotidine 20 and $40 \mathrm{mg}$ bid versus placebo as maintenance therapy in patients with healed erosive esophagitis

\begin{tabular}{|c|c|c|c|}
\hline \multicolumn{4}{|c|}{ Patients with relapse of erosive esophagitis $(\%)^{\dagger}$} \\
\hline Time period & $20 \mathrm{mg}$ bid $(n=110)$ & $40 \mathrm{mg}$ bid $(n=108)$ & Placebo $(n=49)$ \\
\hline Month 3 & 22.0 & 21.5 & 28.8 \\
\hline Month 6 & $29.6^{* *}$ & $29.2^{* *}$ & 56.5 \\
\hline \multicolumn{4}{|c|}{ Prevention of global symptomatic deterioration ${ }^{\ddagger}$} \\
\hline Time period & $20 \mathrm{mg}$ bid $(n=110)$ & $40 \mathrm{mg}$ bid $(n=108)$ & Placebo $(n=49)$ \\
\hline Month 3 & $82.7^{* *}$ & $82.4^{* *}$ & 67.3 \\
\hline Month 6 & $66.4^{*}$ & $68.5^{*}$ & 55.1 \\
\hline
\end{tabular}

" $P<0.05 ; "$ " $P<0.01$ versus placebo: ${ }^{\dagger}$ Relapse defined as recurrence of endoscopically verified erosive esophagitis; ${ }^{\dagger}$ Prevention defined as no or slight deterioration

22 patients (with gastroesophageal reflux and erosive or ulcerative esophagitis) randomized into a double-blind study comparing the effect of omeprazole 20 $\mathrm{mg}$ od with ranitidine $150 \mathrm{mg}$ bid.

Omeprazole significantly reduced the total number of reflux episodes, the number of reflux episodes lasting longer than 5 mins and the total reflux time, whereas ranitidine reduced only the reflux time (70). Of course, it is recog. nized that this dose of omeprazole achieves a greater percentage of intragastric $\mathrm{pH}$ readings over 4 than does this low dose of ranitidine (Figure 19), and higher doses of ranitidine may be needed to treat GERD. When higher doses of ranitidine are used (eg, $300 \mathrm{mg}$ bid), then the two antisecretory agents show similar effects on esophageal acid exposure (27).

Fiorucci and colleagues (25) have examined a small group of patients with moderately severe esophagitis treated with ranitidine $300 \mathrm{mg}$ bid or omeprazole $20 \mathrm{mg}$ bid. The $24 \mathrm{~h}$ intragastric
$\mathrm{pH}$ was numerically higher in patients treated with omeprazole compared with ranitidine, but the acid secretion rate in $\mathrm{mmol} / \mathrm{L}$, while much lower than in the basal condition, was comparable in the two treatment groups. Of course one presumes that if the intragastric $\mathrm{pH}$ is reduced effectively, the intraesophageal $\mathrm{pH}$ will also decline; this was the case, with a reduction in the percentage of readings in the esophagus under $\mathrm{pH} 4$ falling from 23.9 to $8.5 \%$ with ranitidine and $7.2 \%$ with omeprazole. It remains puzzling why reported healing rates between receptor blockers and pump blockers appear to be large when the differences in acid inhibition using these doses is relatively small.

Combination therapy: Given that the pathogenesis of GERD may result from an imbalance between motility and secretion factors, it would be reasonable to ask whether combination therapy might be useful (Figure 20). Temple et al (89) reported no difference between cimetidine $1600 \mathrm{mg}$ daily compared 


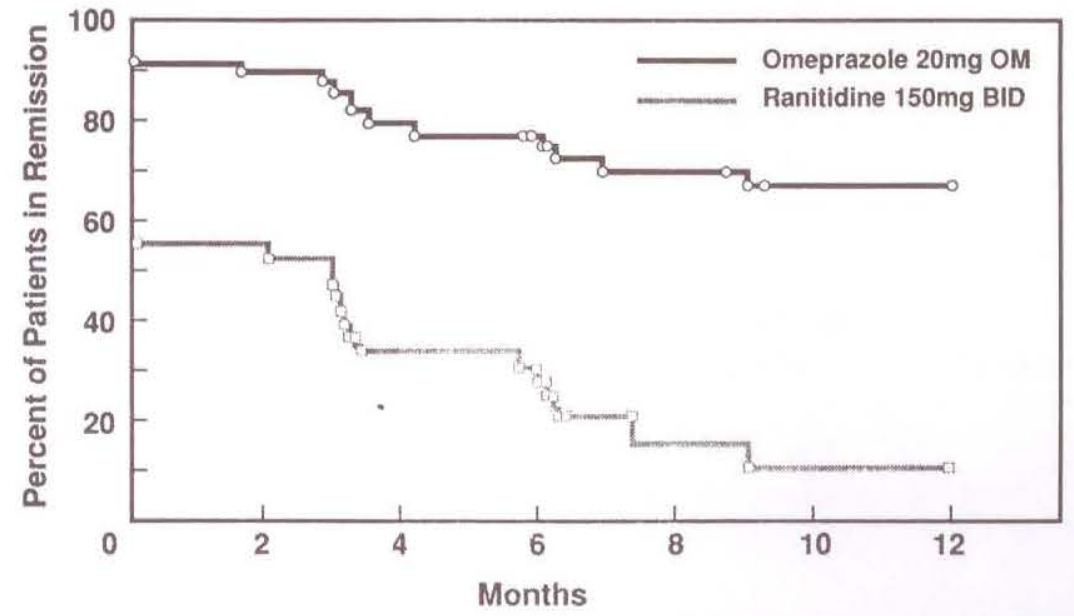

Figure 23) Cumulative proportion of patients in symptomatic and in endoscopic remission when treated with either omeprazole (20 mg once daily) or ranitidine ( $150 \mathrm{mg}$ twice daily) for one year after initial healing of the mucosal lesions. (Reprinted with permission from Lundell et al. Scand J Gastroenterol 1991;26:248-56)

with the same dose of cimetidine plus metoclopramide. And yet, Lieberman and co-workers (90) reported in cimetidine-resistant patients with GERD that the addition of cisapride to cimetidine was superior to cimetidine alone. Cisapride $10 \mathrm{mg}$ bid does not improve upon the effect of ranitidine $150 \mathrm{mg}$ bid (91), but did improve the rate of endoscopic healing from 46 to $70 \%$ when added to cimetidine $1 \mathrm{~g} /$ day (23). The use of pirenzepine $50 \mathrm{mg}$ bid plus ranitidine $150 \mathrm{mg}$ bid had no additional benefits over ranitidine alone in the healing of esophagitis, but did provide superior relief of heartburn and regurgitation (92). The addition of sucralfate to cimetidine alone offers no advantage (93), whereas colloidal bismuth $120 \mathrm{mg}$ qid added to cimetidine $800 \mathrm{mg}$ at night for patients with severe esophagitis gave better results than cimetidine alone (94).

Thus, it is possible that if an individual patient with GERD remains symptomatic after using either a promotility or an antisecretory agent, then combination therapy is worthy of a trial.

Maintenance therapy: Do patients with GERD heal their esophagitis and remain well for long periods? The answer appears to be no (71). Just as duodenal and gastric ulcers recur, esophagitis tends to recur after healing. For example, patients whose esophagi- tis has been healed with a pump blocker or an $\mathrm{H}_{2}$-receptor antagonist will have a recurrence of symptoms and a recurrence of esophagitis at six months (Figure 21). Maintenance therapy, therefore, may be necessary in some patients with GERD.

$\mathrm{H}_{2}$-blockers as maintenance therapy in GERD have been disappointing when used in conventional doses (Figure 22), but symptom relief may be achieved with cimetidine $400 \mathrm{mg}$ at bedtime (38). Just as it may be necessary to use higher doses for acute healing of GERD, it may also be necessary to use higher doses for maintenance therapy. This possibility has been studied; both an international and an American sixmonth, randomized, double-blind, placebo controlled trial demonstrated that famotidine $20 \mathrm{mg}$ bid and $40 \mathrm{mg}$ bid had comparable superiority over placebo in the prevention of relapse of erosive esophagitis and in the prevention of global symptomatic deterioration in patients whose GERD had previously healed with famotidine $(95,96)$ (Tables 10,11$)$. Thus, higher doses of $\mathrm{H}_{2}$-receptor antagonists may indeed be necessary to maintain healing of GERD.

Omeprazole is effective for maintenance therapy in patients with GERD. Lundell et al (97) studied 98 GERD patients who had been treated to en- doscopic healing using omeprazole 40 $\mathrm{mg}$ od or ranitidine $600 \mathrm{mg}$ daily (Figure 23). The patients were then placed on 12 months of maintenance therapy with either omeprazole $20 \mathrm{mg}$ daily or ranitidine $150 \mathrm{mg}$ bid. About one-quarter of the omeprazole-treated patients relapsed compared with more than one-half of ranitidine-treated individuals (Figure 23). This improvement with omeprazole was achieved without any effects on oxyntic mucosal endocrine cells and with only a marginal and biologically insignificant increase in basal serum gastrin concentrations.

Alternate day omeprazole $20 \mathrm{mg}$ may also be effective in maintaining healing and alleviating symptoms in GERD (98). Interestingly, acetylsalicylic acid use may be a factor in the resistance of esophagitis to some therapies, and may also be a factor in the frequent and rapid relapse which may occur if therapy is stopped (99).

Cisapride $20 \mathrm{mg}$ bid is superior to placebo in the maintenance of healing of grades I to III esophagitis previously healed with antisecretory agents (100). Two studies presented at the recent World Congresses of Gastroenterology (in Sydney, Australia in 1990) (101, 102) also suggested that cisapride 10 $\mathrm{mg}$ bid or $20 \mathrm{mg}$ at night is superior to placebo in preventing relapse in patients with GERD. Six-month relapse rates remain high when ranitidine is taken as $300 \mathrm{mg}$ at night or $150 \mathrm{mg}$ bid ( 41 and $37.5 \%$, respectively) and do not differ in this study from the relapse rates seen with placebo $(45 \%)$ (103).

\section{CONCLUSIONS}

GERD is a chronic disease, and treating the acute episode of esophagitis does not solve the problem of the high recurrence rate. The mechanisms of GERD focus on the importance of deranged motility patterns (104). When the esophagitis is healed, the abnormal motility (105) and, likely, the higher rates of acid secretion persist. Thus, maintenance therapy must be taken to either lower intragastric $\mathrm{pH}$ - and, therefore, intraesophageal acid exposure - or to enhance the barriers to acid exposure in the esophagus. 


\section{REFERENCES}

1. De Caestecker JS, Blackwell JN, Pryde A, Heading RC. Daytime gastrooesophageal reflux is important in oesophagitis. Gut 1987;28:519-26.

2. Rokkas T, Sladen GE. Ambulatory esophageal $\mathrm{pH}$ recording in gastroesophageal reflux: Relevance to the development of esophagitis. Am J Gastroenterol 1988;83:629.

3. Lieberman DA. 24-hour esophageal $\mathrm{pH}$ monitoring before and after medical therapy for reflux esophagitis. Dig Dis Sci 1988;33:166-71.

4. Emde C, Cilluffo T, Bauerfeind P, Blum AL. Combined esophageal and gastric $\mathrm{pH}$-metry in healthy volunteers. Influence of cable through LES and effect of misoprostol. Dig Dis Sci 1989;34:79-82.

5. Klauser AG, Heinrich C, Schindlbeck NE, Müller-Lissner SA. Is long-term esophageal $\mathrm{pH}$ monitoring of clinical value? Am J Gastroenterol 1989;84:362.

6. Kruse-Andersen S, Wallin L, Madsen $T$. Reflux patterns and related oesophageal motor activity in gastro-oesophageal reflux disease. Gut 1990;31:633-8.

7. Kadakia S, Kikendall J, Maydonovitch C, Johnson L. Effect of smoking on 24 hour ambulatory esophageal $\mathrm{pH}$ monitoring. Gastroenterology 1991;100:A93.

8. Vandenplas Y, Franckx-Goossens A, Pipeleers-Marichal M, Derde MP, Sacré-Smits L. Area under $\mathrm{pH} 4$ : Advantages of a new parameter in the interpretation of esophageal $\mathrm{pH}$ monitoring data in infants. J Pediatr Gastroenterol Nutr 1989;9:34-9.

9. Robertson DAF, Aldersley MA, Shepherd H, Lloyd RS, Smith, CL. $\mathrm{H}_{2}$ antagonists in the treatment of reflux oesophagitis: Can physiological studies predict the response? Gut 1987;28:946-9.

10. Smout, AJPM, Breedijk M, Van der Zouw C, Akkermans LMA.

Physiological gastroesophageal reflux and esophageal motor activity studied with a new system for 24-hour recording and automated analysis. Dig Dis Sci 1989;34:372-8.

11. Klinkenberg-Knol EC, Meeuwissen SGM. Combined gastric and oesophageal 24-hour $\mathrm{pH}$ monitoring and oesophageal manometry in patients with reflux disease, resistant to treatment with omeprazole. Aliment Pharmacol Therap 1990;4:485-95.

12. Johansson KE, Ask P, Boeryd B, Fransson S-G, Tibbling L. Oesophagitis, signs of reflux, and gastric acid secretion in patients with symptoms of gastro-oesophageal reflux disease. Scand J Gastroenterol 1986;21:837-47.

13. Barlow AP, DeMeester TR, Ball SC, Eypasch EP. The significance of the gastric secretory state in gastroesophageal reflux disease. Arch Surg 1989;124:937-40.

14. Collen MJ, Lewis JH, Benjamin SB. Gastric acid hypersecretion in refractory gastroesophageal reflux disease. Gastroenterology 1990;98:654-61.

15. Tytgat GNJ, Nio CY, Schotborgh RH. Reflux esophagitis. Scand J Gastroenterol 1990;25(Suppl 175):1-12.

16. Reynolds JC. Prokinetic agents: A key in the future of gastroenterology. Gastroenterol Clin North Am 1989;18:437-58.

17. Richter JE. Efficacy of cisapride on symptoms and healing of gastro-oesophageal reflux disease: A review. Scand J Gastroenterol 1989;24 (Suppl 165):19-28.

18. Collins BJ, Spence RAJ, Ferguson R, Laird J, Love AHG. Cisapride: Influence on oesophageal and gastric emptying and gastro-oesophageal reflux in patients with reflux oesophagitis. Hepato-gastroenterol 1987;34:113-6.

19. Ceccatelli P, Janssens J, Vantrappen G, Cucchiara S. Cisapride restores the decreased lower oesophageal sphincter pressure in reflux patients. Gut 1988;29:631-5.

20. Urbain JL, Siegel JA, Debie NC, Pauwels SP. Effect of cisapride on gastric emptying in dyspeptic patients. Dig Dis Sci 1988;33:779-83.

21. Rezende-Filho J, Di Lorenzo C, Dooley $\mathrm{CP}$, Valenzuela JE. Cisapride stimulates antral motility and decreases biliary reflux in patients with severe dyspepsia. Dig Dis Sci 1989;34:1057-62.

22. Janisch HD, Hüttemann W, Bouzo $\mathrm{MH}$. Cisapride versus ranitidine in the treatment of reflux esophagitis. Hepato-gastroenterol 1988;35:125-7.

23. Galmiche JP, Fraitag B, Filoche B, et al. Double-blind comparison of cisapride and cimetidine in treatment of reflux esophagitis. Dig Dis Sci 1990;35:649-55

24. Burget DW, Chiverton SG, Hunt RH. Is there an optimal degree of acid suppression for healing of duodenal ulcers? Gastroenterology 1990;99:345-51

25. Fiorucci S, Santucci L, Morelli A. Effect of omeprazole and high doses of ranitidine on gastric acidity and gastroesophageal reflux in patients with moderate-severe esophagitis. Am J Gastroenterol 1990;95:1458-62.

26. Barlow A, Watson A, Attwood S,
Dixon JS, Johnson NJ. A double-blind crossover comparison of the effects of ranitidine $300 \mathrm{mg}$ qds, $150 \mathrm{mg}$ bd and placebo on intragastric acidity and intraoesophageal $\mathrm{pH}$. Gastroenterology 1991;100:A30.

27. Fiorucci S, Santucci L, Perrone E, Abbritti F, Morelli A. Gastric and esophageal acidity during continuous treatment with $\mathrm{H}_{2}$-antagonists in uncomplicated esophagitis. Scand ] Gastroenterol 1989;24:671-7.

28. Behar J, Brand DL, Brown FC, et al. Cimetidine in the treatment of symptomatic gastroesophageal reflux. Gastroenterology 1978;74:441-8.

29. Breen KJ, Desmond PV, Whelan G. A randomized, controlled evaluation of cimetidine. Med J Aust 1983;2:555-6.

30. Bright-Asare P, El-Bassoussi M. Cimetidine, metoclopramide, or placebo in the treatment of symptomatic gastroesophageal reflux. J Clin Gastroenterol 1980;2:149-56.

31. Brown P. Cimetidine in the treatment of reflux esophagitis. Med J Aust 1979;2:96-7.

32. Ferguson R, Dronfield MW, Atkinson $\mathrm{M}$. Cimetidine in the treatment of reflux oesophagitis with peptic stricture. Br Med J 1979;2:472-4.

33. Festen HPM, Driessen WMM, Lamers $\mathrm{CBH}$, Van Tongeren JHM.

Cimetidine in the treatment of severe ulcerative reflux oesophagitis: Results of an 8-week double-blind study and of subsequent long-term maintenance treatment. Neth J Med 1980;23:237-40.

34. Fiasse R, Hanin C, Lepot A, Descamps C, Lamy F, Dive C. Controlled trial of cimetidine in reflux esophagitis. Dig Dis Sci 1980;25:750-5.

35. Greaney MG, Irvin TT. Cimetidine for the treatment of symptomatic gastro-oesophageal reflux. $\mathrm{Br} \mathrm{J}$ Clin Prac 1981;35:21-4.

36. Powell-Jackson $\mathrm{P}$, Barkley $\mathrm{H}$, Northfield TC. Effect of cimetidine in symptomatic gastro-oesophageal reflux. Lancet 1978;ii:1068-9.

37. Wesdorp E, Bartelsman J, Pape K, Dekker W, Tytgat GN. Oral cimetidine in reflux esophagitis: A double blind controlled trial. Gastroenterology 1978;74:821-4.

38. Kaul B, Petersen H, Erichsen $\mathrm{H}$, et al. Acute and maintenance treatments with cimetidine. Scand J Gastroenterol 1986;21:139-45.

39. Archambault AP, Farley A, Cleator IG, et al. Cimetidine therapy for gastroesophageal reflux disease. West J Med 1985;143:616-21.

40. Cloud M, Offen W. Nizatidine $150 \mathrm{mg}$ bid relieves symptoms and decreases severity of esophagitis in 
gastro-oesophageal reflux disease. Gastroenterology 1989;96:A91.

41. Quik RPF, Cooper MJ, Gleeson M, et al. A comparison of two doses of nizatidine versus placebo in the treatment of reflux oesophagitis. Aliment Pharmacol Therap 1990;4:201-11.

42. Berges W, Lux G, Simon B, Weinbeck M, Quik R. A comparison of two doses of nizatidine in reflux oesophagitis. Z Gastroenterol 1989;27:156.

43. Orr WC, Finn A, Wilson T, Russell J. Esophageal acid contact time and heartburn in acute treatment with ranitidine and metoclopramide. Am J Gastroenterol 1990;85:697-704.

44. Berstad A. Overview of ranitidine in reflux oesophagitis: Its effect on symptoms, endoscopic appearance and histology. In: Misiewicz JJ, Wormsley $\mathrm{KG}$, eds. The Clinical Use of Ranitidine. Oxford: Medicine Publishing Foundation, 1982:297-304.

45. Goy JA, Maynard JH, McNauton WM, O'Shea A. Ranitidine and placebo in the treatment of reflux oesophagitis. Med J Aust 1983;2:558-61.

46. Grove O, Bekker C, Jeppe-Hansen MG, et al. Ranitidine and high dose antacid in reflux esophagitis. A randomized placebo-controlled trial. Scand J Gastroenterol 1985;20:457-61.

47. Hine KR, Holmes GKT, Melikian V, Lucey M, Fairclough PD. Ranitidine in reflux oesophagitis. Digestion 1984;29:119-23.

48. Johansson KE, Boeryd B, Johansson K, Tibbling L. Double-blind crossover study of ranitidine and placebo in gastro-oesophageal reflux disease. Scand J Gastroenterol 1986;21:769-78.

49. Lehtola J, Niemelä S, Martikainen J, Krekelä I. Ranitidine, $150 \mathrm{mg}$ three times a day, in the treatment of reflux oesophagitis. A placebo-controlled, double-blind study. Scand J Gastroenterol 1986;21:175-80.

50. Sherbaniuk R, Wensel R, Bailey R, et al. Ranitidine in the treatment of symptomatic gastroesophageal reflux disease. J Clin Gastroenterol 1984;6:9-15.

51. Sontag S, Robinson M, McCallum RW, Barwick KW, Nardi R.

Ranitidine therapy for gastroesophageal reflux disease. Results of a large double-blind trial. Arch Intern Med 1987;147:1485-91.

52. Wesdorp ICE, Dekker E, KlinkenbergKnol EC. Treatment of reflux oesophagitis with ranitidine. Gut 1983;24:921-4.

53. Bovero E, Cheli R, Barbara L, et al. Short-term treatment of reflux oesophagitis with ranitidine $300 \mathrm{mg}$ nocte, Italian multicentre study.
Hepato-gastroenterology 1987;34:155-9.

54. Halvorsen L, Lee FI, Wesdorp ICE, Johnson NJ, Mills JG, Wood JR. Acute treatment of reflux oesophagitis: A multi-centre study to compare 150 mg ranitidine twice daily with $300 \mathrm{mg}$ ranitidine at bedtime. Aliment Pharmacol Therap 1989;3:171-81.

55. Schaub N, Meyrick TJ, Misiewicz JJ, Lovell D, Trotman IF. Investigation of ranitidine $150 \mathrm{mg}$ bid or $300 \mathrm{mg}$ bid in the treatment of reflux disease. Hepato-gastroenterol 1986;33:208-13.

56. Johnson NJ, Mills JG, Wood JR. Acute treatment of reflux oesophagitis: a multi-centre trial comparing ranitidine $150 \mathrm{mg}$ bid with ranitidine $300 \mathrm{mg}$ qid. Gastroenterology 1989;96:A242.

57. Euler AR, Murdock RH, Wilson RH. Ranitidine is effective in healing erosive esophagitis. Gastroenterology 1991;100:A61.

58. Festen HPM, Wesdorp, ICE, Dekker $\mathrm{W}$, et al. The efficacy of famotidine 20 $\mathrm{mg}$ bid vs $40 \mathrm{mg}$ bid in the treatment of erosive/ulcerative reflux esophagitis: Significance of severity of esophagitis and duration of therapy. Gastroenterology 1991;100:A63.

59. Fielding JF. Doyle GD. Comparison between ranitidine and cimetidine in the treatment of reflux oesophagitis. Ir Med J 1984;77:356-7.

60. Guslandi M, Testoni PA, Passaretti S, et al. Ranitidine versus metoclopramide in the medical treatment of reflux esophagitis. Hepato-gastroenterol 1983;30:96-8.

61. Sekiguchi T, Nishioka T, Kogure M, et al. Once daily famotidine for reflux esophagitis. Scand J Gastroenterol 1987;22(Suppl 134):51-4.

62. Berenson M, Simon TJ, Berlin RG, et al. BID regimens of an $\mathrm{H}_{2}$-receptor antagonist heal erosive esophagitis: Results of a US double-blind, randomised multicenter trial. Gastroenterology 1990;98:A372.

63. Simon TJ, Berlin RG, Tipping RW, et al. Results of an international double-blind, multicenter trial comparing bid dosages of $\mathrm{H}_{2}$ receptor antagonists: Relationship between pharmacodynamic effect on esophageal reflux and healing of erosive esophagitis. Am J Gastroenterol 1990;85:1225.

64. Sabesin SM, Schaffner JA, Bradstreet DJ, Walton-Bowen K, Humphries TJ. Famotidine-symptomatic relief and healing in patients with reflux esophagitis: Results of a US multi-center trial. Gastroenterology 1990;98:A117.

65. Johnsson LR, DeMeester TR. Twenty-four hour $\mathrm{pH}$ monitoring of the distal esophagus: A quantitative measure of gastroesophageal reflux. Am J Gastroenterol 1974;62:325-33.

66. DeMeester TR, Wang CI, Wernly JA, et al. Technique, indications and clinical use of 24 hour esophageal $\mathrm{pH}$ monitoring. J Thorac Cardiovasc Surg 1980;79:656-67.

67. Horowitz M, Hetzel DJ, Buckle PJ, Chatterton BE, Shearman DJ. The effect of omeprazole on gastric emptying in patients with duodenal ulcer disease. Brit J Clin Pharmacol 1984;18:791-4.

68. Dent J, Downton J, Buckle P, et al. Omeprazole heals peptic esophagitis by elevation of intragastric $\mathrm{pH}$. Gastroenterology 1985;88:1363.

69. Pasqual JC, Hémery P, Bruley S, Galmiche JP. Comparison of the effects of two doses of omeprazole on 24-hour oesophageal $\mathrm{pH}$ in gastroesophageal reflux disease. Gastroenterology 1987;92:1567.

70. Ruth M, Enbom H, Lundell H, Lönroth H, Sandberg N, Sandmark S. The effect of omeprazole or ranitidine treatment on 24-hour oesophageal acidity in patients with reflux esophagitis. Scand J Gastroenterol 1988;23:1141-6.

71. Hetzel DJ, Dent J, Reed WD, et al. Healing and relapse of severe peptic oesophagitis after treatment with omeprazole. Gastroenterology 1988;95:903-12.

72. Dammann HG, Blum AL, Lux G, et al. Omeprazole is superior to ranitidine in the treatment of reflux oesophagitis. Gastroenterology 1986;90:1385.

73. Zeitoun P, Desjars de Keranroué N, Isal JP. Omeprazole versus ranitidine in erosive oesophagitis. Lancet 1987;ii:621-2.

74. Sandmark S, Carlsson R, Fausa O, Lundell L. Omeprazole or ranitidine in the treatment of reflux esophagitis. Scand J Gastroenterol 1988;23:625-32.

75. Havelund T, Laursen LS, Skoubo-Kristensen E, et al. Omeprazole and ranitidine in treatment of reflux oesophagitis: A double blind comparative trial. $\mathrm{Br}$ Med J 1988;296:89-92.

76. Vantrappen G, Rutgeerts L, Schurmans P, Coenegrachts JL. Omeprazole ( $40 \mathrm{mg}$ ) is superior to ranitidine in short-term treatment of ulcerative reflux esophagitis. Dig Dis Sci 1988;33:523-9.

77. Klinkenberg-Knol EC, Jansen JMBJ, Festen HPM, Meuwissen, SGM, Lamers CBHW. Double-blind multicentre comparison of omeprazole and ranitidine in the treatment of reflux oesophagitis. Lancet 1987;i:349-51. 
78. Dehn TCB, Shepherd HA, Colin-Jones D, Kettlewell MGW, Carroll NJH. Double blind comparison of omeprazole ( $40 \mathrm{mg} \mathrm{od}$ ) versus cimetidine ( $400 \mathrm{mg}$ qd) in the treatment of symptomatic erosive reflux oesophagitis, assessed endoscopically, histologically and by $24 \mathrm{~h} \mathrm{pH}$ monitoring. Gut 1990;31:509-13.

79. Blum AL, Wienbeck M, Schiessel R, Carlsson R. Omeprazole is superior to ranitidine in the treatment of reflux esophagitis. Hepato-gastroenterology 1989;36:F14.

80. Lundell GE, Westin IH, Sandmark S, et al. Omeprazole or high dose ranitidine in the treatment of patients with reflux esophagitis not responding to standard doses of $\mathrm{H}_{2}$-receptor antagonists. Gastroenterology 1989;96:A310.

81. Bate CM, Keeling PWN, O'Morain C, et al. Comparison of omeprazole and cimetidine in reflux oesophagitis: Symptomatic, endoscopic, and histological evaluations. Gut 1990;31:968-72.

82. Bate CM, Keeling PWN, O'Morain $\mathrm{CA}$, et al. Omeprazole heals reflux oesophagitis in a greater proportion of patients than cimetidine, assessed endoscopically, histologically and symptomatically. Hepatogastroenterology 1989;36:F13.

83. Bate CM, Keeling PWN, O'Morain $\mathrm{CA}$, et al. Omeprazole provides faster healing and symptom relief of reflux oesophagitis than cimetidine. Gut 1989;30:A1493.

84. Holt S, Howden CW. Omeprazole. Overview and opinion. Dig Dis Sci 1991;36:385-93.

85. Ching CK, Shaheen MZ, Holmes GKT. Is omeprazole more effective in the treatment of resistant reflux oesophagitis and associated peptic stricture? Gastroenterology 1990;98:A30.

86. Deviere J, Buset M, Dumonceau JM,
Rickaert F, Cremer M. Regression of Barrett's epithelium with omeprazole. N Engl J Med 1989;320:1495-7.

87. Bardhan KD, Morris P, Thompson M, et al. Omeprazole in the treatment of erosive esophagitis refractory to high dose cimetidine and ranitidine. Gut 1990;31:745-9.

88. Marciano-D'Amore DA, Paterson WG, DaCosta LR, Beck IT. Omeprazole in $\mathrm{H}_{2}$ receptor antagonist-resistant reflux esophagitis. J Clin Gastroenterol 1990;12:616-20.

89. Temple JG, Bradby GVH, O'Connor $\mathrm{F}$, et al. Cimetidine and metoclopramide in oesophageal reflux disease. Br Med J 1983;296:1863-4.

90. Lieberman DA, Keeffe EB. Treatment of severe reflux esophagitis with cimetidine and metoclopramide. Ann Intern Med 1986;104:21-6.

91. Wienbeck, M. Does cisapride added to $\mathrm{H}_{2}$-receptor-blocking treatment improve healing rates in patients with esopahgitis? Digestion 1986;34:144.

92. Londong W, Phillips J, Johnson NJ, Wood JR. The effect of combined therapy with ranitidine and pirenzepine in the treatment of reflux oesophagitis. Gastroenterology 1991;100:A113.

93. Schotbrogh RH, Hameeteman W, Dekker W, et al. Combination therapy of sucralfate and cimetidine, compared with sucralfate monotherapy, in patients with peptic reflux esophagitis. Am J Med 1989;6A(Suppl):77-80.

94. Borkent MV, Beker JA. Treatment of ulcerative reflux oesophagitis with colloidal bismuth subcitrate in combination with cimetidine. Gut 1988;29:385-9.

95. Stein DT, Simon TJ, Berlin RG, et al. Controlling 24 hour esophageal acid exposure in patients with healed erosive esophagitis prevents endoscopic recurrence and symptomatic deterioration: Results of a 6 month, randomized, doubleblind US placebo-controlled trial comparing famotidine $20 \mathrm{mg}$ bid and $40 \mathrm{mg}$ bid. Gastroenterology 1990;100:A167.

96. Simon TJ, Berlin RG, Tipping R, et al. Prevention of endoscopic recurrence of erosive esophagitis with famotidine $20 \mathrm{mg}$ bid and $40 \mathrm{mg}$ bid: Results of an international 6 month, randomized, double-blind, placebocontrolled trial. Gastroenterology 1990;10:A162.

97. Lundell GE, Backman L, Ekström P, et al. Prevention of relapse of reflux esophagitis after endoscopic healing: The efficacy and safety of omeprazole compared with ranitidine. Scand ] Gastroenterol 1991;26:248-56.

98. Bank S, Greenberg R. Alternate day omeprazole in $\mathrm{H}_{2}$ receptor-antagonist resistant reflux esophagitis.

Gastroenterology 1990;100:A29.

99. Lanas A, Hirschowitz BI. Significant role of aspirin use in esophagitis. Gastroenterology 1991;100:A106.

100. Tytgat GNJ and the Scanedcis Trialists. Effect of cisapride on relapse of reflux esohagitis healed with an antisecretory drug. Gastroenterol 1991;100:A178.

101. Blum AL. Cisapride reduces the relapse rate in reflux oesophagitis. World Congresses of Gastroenterology, 1990.

102. Verlinden M, Reyntjens A. Cisapride prevents relapse of reflux oesophagitis. World Congresses of Gastroenterology, 1990.

103. Armstrong D, Blum AL. Full dose $\mathrm{H}_{2}$-receptor antagonist prophylaxis does not prevent relapse of reflux esophagitis. Gut 1989;30:A1494.

104. Koelz HR. Treatment of reflux esophagitis with $\mathrm{H}_{2}$-blockers, antacids and prokinetic drugs. Scand J Gastroenterol 1989;24(Suppl 156):25-36.

105. Sontag S]. The medical management of reflux esophagitis. Role of antacids and acid inhibition. Gastroenterol Clinics North Am 1990;19:683-712. 


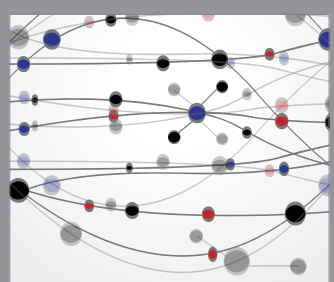

The Scientific World Journal
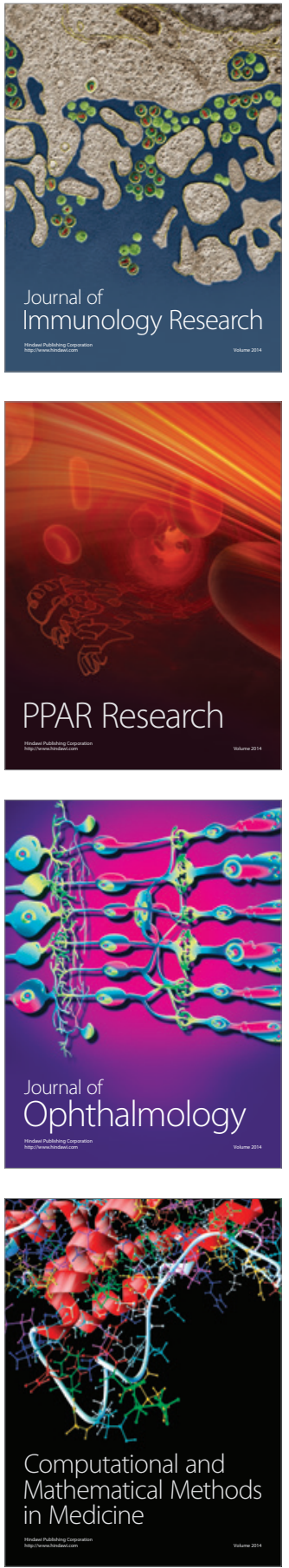

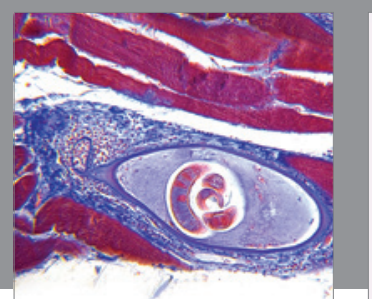

Gastroenterology Research and Practice

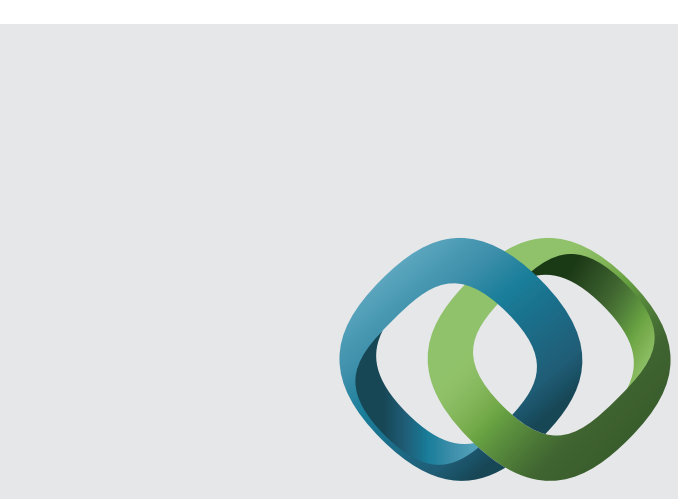

\section{Hindawi}

Submit your manuscripts at

http://www.hindawi.com
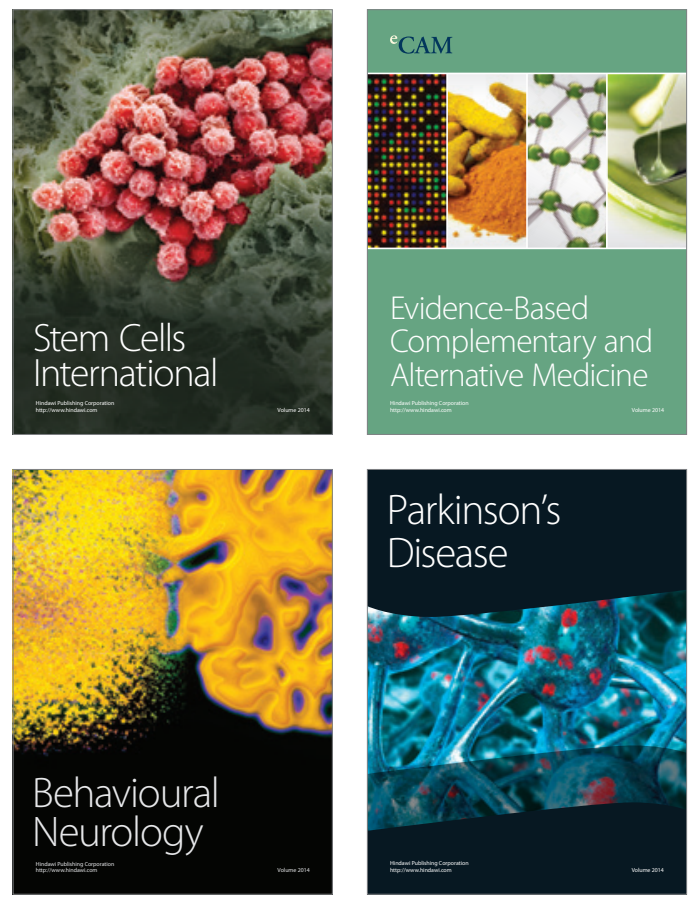
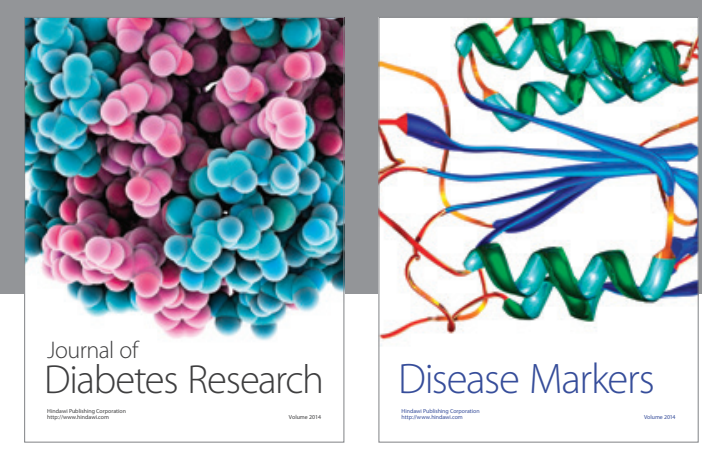

Disease Markers
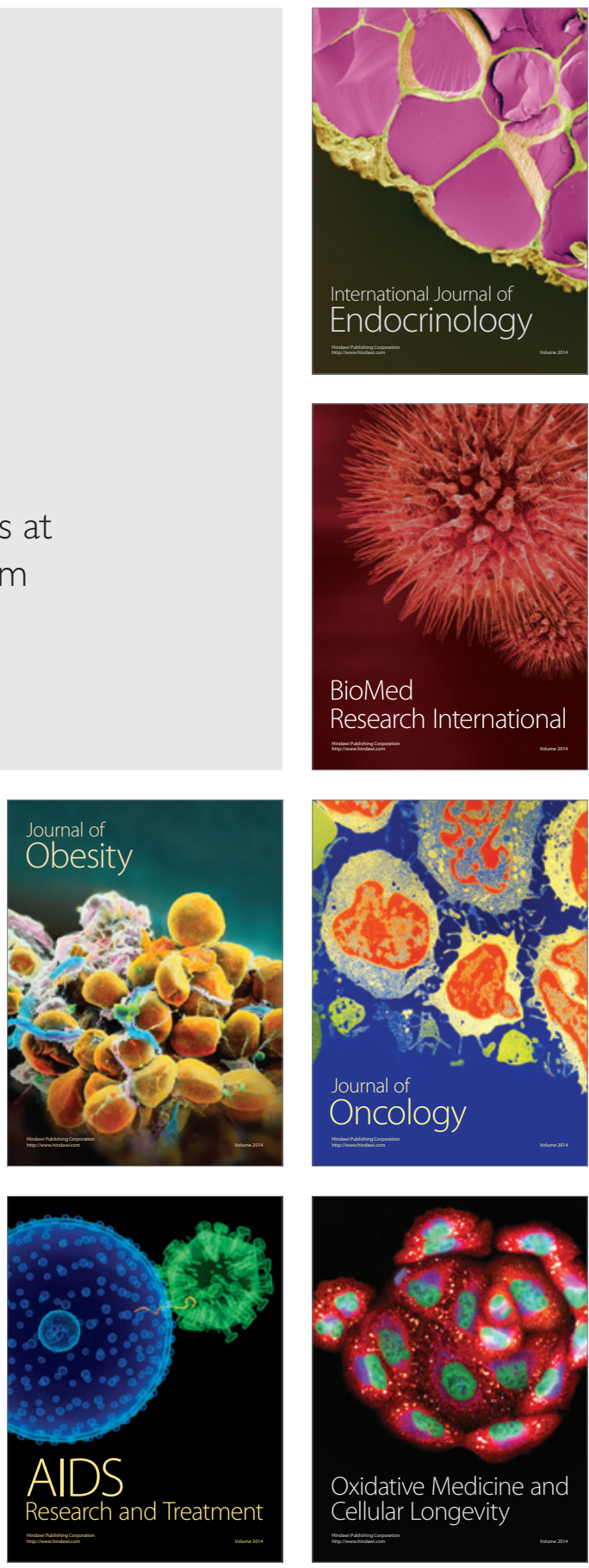